\title{
Distribution and cycling of terrigenous dissolved organic carbon in peatland-draining rivers and coastal waters of Sarawak, Borneo
}

\author{
Patrick Martin $^{1}$, Nagur Cherukuru ${ }^{2}$, Ashleen S. Y. Tan ${ }^{1, \text { a }}$, Nivedita Sanwlani ${ }^{1}$, Aazani Mujahid ${ }^{3}$, and Moritz Müller ${ }^{4}$ \\ ${ }^{1}$ Asian School of the Environment, Nanyang Technological University, Singapore 639798, Singapore \\ ${ }^{2}$ CSIRO Oceans and Atmosphere Flagship, Canberra ACT 2601, Australia \\ ${ }^{3}$ Department of Aquatic Science, Faculty of Resource Science \& Technology, University Malaysia Sarawak, \\ 94300 Kota Samarahan, Sarawak, Malaysia \\ ${ }^{4}$ Swinburne University of Technology, Faculty of Engineering, Computing and Science, 93350 Kuching, Sarawak, Malaysia \\ ${ }^{\mathrm{a}}$ current address: Erasmus Mundus Joint Programme in Marine Environment and Resources, Plentzia Marine Station, \\ University of the Basque Country, Plentzia, Spain
}

Correspondence: Patrick Martin (pmartin@ntu.edu.sg)

Received: 28 August 2018 - Discussion started: 11 September 2018

Revised: 30 October 2018 - Accepted: 5 November 2018 - Published: 16 November 2018

\begin{abstract}
South-East Asia is home to one of the world's largest stores of tropical peatland and accounts for roughly $10 \%$ of the global land-to-sea dissolved organic carbon (DOC) flux. We present the first ever seasonally resolved measurements of DOC concentration and chromophoric dissolved organic matter (CDOM) spectra for six peatlanddraining rivers and coastal waters in Sarawak, north-western Borneo. The rivers differed substantially in DOC concentration, ranging from $120-250 \mu \mathrm{mol} \mathrm{L}^{-1}$ (Rajang River) to 3100-4400 $\mu \mathrm{mol} \mathrm{L}^{-1}$ (Maludam River). All rivers carried high CDOM concentrations, with $a_{350}$ in the four blackwater rivers between 70 and $210 \mathrm{~m}^{-1}$ and 4 and $12 \mathrm{~m}^{-1}$ in the other two rivers. DOC and CDOM showed conservative mixing with seawater except in the largest river (the Rajang), where DOC concentrations in the estuary were elevated, most likely due to inputs from the extensive peatlands within the Rajang Delta. Seasonal variation was moderate and inconsistent between rivers. However, during the rainier north-east monsoon, all marine stations in the western part of our study area had higher DOC concentrations and lower CDOM spectral slopes, indicating a greater proportion of terrigenous DOM in coastal waters. Photodegradation experiments revealed that riverine DOC and CDOM in Sarawak are photolabile: up to $25 \%$ of riverine DOC was lost within 5 days of exposure to natural sunlight, and the spectral slopes of photo-bleached CDOM resembled those of our marine samples. We conclude that coastal waters of Sarawak receive large inputs of ter-
\end{abstract}

rigenous DOC that is only minimally altered during estuarine transport and that any biogeochemical processing must therefore occur mostly at sea. It is likely that photodegradation plays an important role in the degradation of terrigenous DOC in these waters.

\section{Introduction}

The annual flux of terrigenous dissolved organic carbon (tDOC) from rivers into the sea is an important part of the global carbon cycle, estimated at around $0.2 \mathrm{Pg} \mathrm{Cyr}^{-1}$ (Dai et al., 2012). South-East Asian rivers contribute roughly $10 \%$ of this flux (Baum et al., 2007; Huang et al., 2017; Moore et al., 2011), chiefly owing to the extensive peat deposits along the coasts of Borneo and Sumatra (Dommain et al., 2014; Page et al., 2011). The rivers draining these peatlands typically carry millimolar concentrations of DOC and are often called "blackwater" rivers (Alkhatib et al., 2007; Baum et al., 2007; Cook et al., 2017; Moore et al., 2011; Rixen et al., 2008).

However, our understanding of the fate of tDOC in rivers, estuaries, and in the ocean is still limited. Most tDOC is derived from soils, from which it is leached by rainwater, and it is thus rich in lignin and humic substances. Classically, these high-molecular weight, highly aromatic molecules have been assumed to be inherently refractory to degradation (Bianchi, 
2011), which would imply that they should accumulate in the ocean. However, dissolved organic matter (DOM) in the open ocean does not show clear chemical signatures of terrigenous origin, which indicates that terrigenous DOM (tDOM) must be partly remineralised and chemically altered before reaching the open ocean (Bianchi, 2011; Cai, 2011). Although it is now established that tDOM is indeed partly labile to both photo-oxidation (Helms et al., 2014; Miller and Zepp, 1995; Moran et al., 2000; Spencer et al., 2009; White et al., 2010) and microbial degradation (Fasching et al., 2014; Leff and Meyer, 1991; Moran and Hodson, 1990; Obernosterer and Benner, 2004; Stutter and Cains, 2016; Ward et al., 2013), we are still far from having a quantitative understanding of tDOM processing in estuaries and shelf seas globally. For example, some studies have reported major losses of tDOM, with $40 \%-50 \%$ of the tDOC flux being remineralised on the Louisiana Shelf and in the Eurasian Arctic shelf sea (Fichot and Benner, 2014; Kaiser et al., 2017). Yet in contrast, recent analysis of carbon isotopes in different molecular weight fractions in the open ocean suggests that a larger proportion of oceanic DOM may have a more terrigenous origin than currently thought (Zigah et al., 2017). High-resolution mass spectrometry has also identified new terrigenous biomarkers and shown that they are widely distributed throughout the oceans (Medeiros et al., 2016). Moreover, experimental work has clearly shown that some tDOM fractions are resistant to photodegradation (Stubbins et al., 2017). Clearly, more work is needed to trace tDOM fluxes through estuaries and to determine where, how, and to what degree tDOM is biogeochemically processed.

Because tDOM is rich in chromophoric dissolved organic matter (CDOM), optical measurements are commonly used as proxies to trace tDOM fluxes into the ocean (Chen et al., 2015; Fichot and Benner, 2012; Fichot et al., 2016; Kowalczuk et al., 2003; Osburn et al., 2016; Yamashita et al., 2011). The last decade in particular has seen significant advances in our understanding of how CDOM spectral characteristics vary between $\mathrm{TDOM}$ and marine DOM, and how they are affected by different biogeochemical processes (Hansen et al., 2016; Helms et al., 2008, 2013, 2014; Shank et al., 2005). As a result, CDOM spectral slope coefficients in the ultraviolet (UV) part of the spectrum have emerged as a robust way to trace tDOM fluxes across salinity gradients and to infer biogeochemical transformations of tDOM (Chen et al., 2015; Fichot et al., 2014, 2016; Helms et al., 2008; Osburn et al., 2016; Stedmon and Markager, 2003).

So far, however, most studies of tDOM fluxes to the sea have focused on North America (Chen et al., 2015; Durako et al., 2010; Fichot and Benner, 2014; Fichot et al., 2014; Leech et al., 2016; Medeiros et al., 2017), Europe (Painter et al., 2018; Rathgeb et al., 2017; Stedmon et al., 2000; Yamashita et al., 2011), and the Arctic (Benner et al., 2005; Dittmar, 2004; Kaiser et al., 2017; Semiletov et al., 2016). Much less work has been conducted in South-East Asia, despite the disproportionately large fluxes of tDOC through South-
East Asia's peatland-draining rivers. Most research in SouthEast Asia has focused on the peatlands themselves to quantify their extent, carbon stocks, and biogeochemistry (Cobb et al., 2017; Dommain et al., 2014; Gandois et al., 2013, 2014; Gastaldo, 2010; Page et al., 2011) or has just examined rivers and estuaries but not traced tDOM further beyond the coast (Alkhatib et al., 2007; Baum et al., 2007; Cook et al., 2017; Harun et al., 2016; Müller et al., 2015; Rixen et al., 2008; Wit et al., 2015). Moreover, most studies of rivers focused either on the total DOC concentration (Alkhatib et al., 2007; Baum et al., 2007; Cook et al., 2017; Rixen et al., 2008) or on water-air $\mathrm{CO}_{2}$ fluxes (Müller et al., 2015, 2016; Müller-Dum et al., 2018; Wit et al., 2015). These studies have shown clearly that peatland-draining rivers in Sumatra and Borneo have amongst the highest DOC concentrations reported from any rivers globally (up to $3000-5500 \mu \mathrm{mol} \mathrm{L}^{-1}$ or $36-66 \mathrm{mg} \mathrm{CL}^{-1}$ ). Yet surprisingly, the $\mathrm{CO}_{2}$ fluxes out of these rivers were found to be quite low relative to the extremely high DOC concentrations, implying that most of the tDOC they carry is delivered to the sea (Wit et al., 2015). To understand the biogeochemical processing of South-East Asian tDOC, more work clearly needs to be done in coastal waters. This need is particularly urgent because most peatlands in South-East Asia have been converted to agricultural use over the past two decades (Miettinen et al., 2016) and such conversion appears to enhance riverine tDOC fluxes by destabilising the peatland C pool (Moore et al., 2013).

Here, we present what is to our knowledge the first analysis of DOC concentrations and CDOM spectral properties in six rivers and the surrounding coastal sea in the western part of Sarawak, Malaysian Borneo. Samples were collected at three different times of the year to constrain seasonal variability, and photodegradation experiments were conducted to determine tDOM photolability.

\section{Materials and methods}

\subsection{Study region and sample collection}

Three field expeditions to Sarawak were undertaken in March, June, and September 2017. Six rivers were sampled in March and September: the Rajang ( $\sim 550 \mathrm{~km}$ length $)$, the Maludam ( $~ 33 \mathrm{~km}$ length), the Sebuyau ( $\sim 58 \mathrm{~km}$ length), the Simunjan $(\sim 54 \mathrm{~km}$ length $)$, the Sematan $(\sim 15 \mathrm{~km}$ length), and the Samunsam ( $\sim 34 \mathrm{~km}$ length) (Fig. 1). The June expedition sampled only the Rajang River. On all expeditions, the river estuaries and open coastal waters were sampled (Fig. 1). In September, one sample was also taken in the estuary of a seventh river, the Lundu River (94 km length). All station locations, sampling dates, and measured data are shown in Supplement Table S1; raw data files for measured parameters are available from the NTU Data Repository (Martin, 2018). Four of the rivers (Maludam, Simunjan, Sebuyau, and Samunsam) are blackwater rivers that 
drain catchments with high peatland coverage, while the Sematan and Lundu rivers drain catchments with limited peatland cover. The Rajang River drains mineral soils until it reaches the town of Sibu, from where it branches into multiple distributary channels (Fig. 1). The distributaries each have unique names; the main ones (Rajang, Serendeng, and Igan) are identified in Fig. 1. These distributaries are surrounded by extensive peatlands that drain directly into the distributary channels (Staub et al., 2000). Mangroves grow along the estuaries of all of the rivers. All river samples are distinguished below by river name, while marine samples are distinguished by whether they were collected in the region east of Kuching ("eastern region", influenced strongly by the Rajang River outflow) or in the region west of Kuching ("western region", influenced by the Samunsam and Sematan rivers). The Talang Islands in the western region (Fig. 1) are surrounded by coral reefs.

The three sampling periods corresponded to the end of the north-east monsoon (March, end of the wettest season of the year), the south-west monsoon (June, lower precipitation), and shortly before the beginning of the north-east monsoon (September, end of the drier season). Monthly precipitation across Sarawak can vary several-fold across the year but is mostly $\geq 100 \mathrm{~mm}$ per month (Sa'adi et al., 2017). Precipitation data were obtained from weather stations in Sibu, Maludam, and Sematan. Monthly averages were calculated for the period 1999-2017, omitting the few months for Maludam and Sematan for which there were days with missing data (there were no missing data in 2017). Precipitation in 2017 was mostly within 1 standard deviation of the 19992017 means (Fig. 1e). It should be noted that precipitation in this region is strongly driven by small-scale convective systems; however, 2017 was overall not an unusual year in terms of precipitation. Water temperatures in Sarawak show essentially no seasonal variation (average water temperatures during all expeditions fell within $28.5-29.5^{\circ} \mathrm{C}$ ).

To collect samples in the Rajang River and the eastern region, a live-aboard fishing boat was chartered for 4- to 7-day cruises, and all samples were filtered and preserved upon collection. All other stations were sampled from small outboardpowered boats, in which case samples were stored in the dark at ambient temperature in insulated boxes on board, and filtered back on land each afternoon and evening. All samples were collected within the upper $1 \mathrm{~m}$ using either a bucket or a hand-held jug; sampling devices were rinsed thoroughly with sample water before sampling. Sample water was decanted into either amber borosilicate glass bottles (DOC and CDOM) or HDPE bottles (chlorophyll and total suspended solids).

DOC and CDOM samples were filtered through $0.2 \mu \mathrm{m}$ pore-size Anodisc filters ( $47 \mathrm{~mm}$ diameter) using an all-glass filtration system that was rinsed with $1 \mathrm{M} \mathrm{HCl}$ and ultrapure deionised water $\left(18.2 \mathrm{M} \Omega \mathrm{cm}^{-1}\right.$, referred to as "DI water" below) in between each sample. Each Anodisc filter was rinsed by filtering $100-150 \mathrm{~mL}$ of DI water and then 50
$100 \mathrm{~mL}$ of sample water, before a further $100-150 \mathrm{~mL}$ of sample water were filtered and taken as the sample. DOC samples $(30 \mathrm{~mL})$ were immediately acidified with $100 \mu \mathrm{L}$ of either $25 \% \mathrm{H}_{3} \mathrm{PO}_{4}$ (March expedition) or $50 \% \mathrm{H}_{2} \mathrm{SO}_{4}$ (all other samples) to $\mathrm{pH}<2.0$. CDOM samples $(30 \mathrm{~mL})$ were preserved with $150 \mu \mathrm{L}$ of $10 \mathrm{~g} \mathrm{~L}^{-1} \mathrm{NaN}_{3}$ following Tilstone et al. (2002). DOC and CDOM samples were stored in amber borosilicate vials with PTFE-lined septa at $+4{ }^{\circ} \mathrm{C}$ until analysis (within 1.5 months of collection), although some river samples in September froze for 1-2 days due to a refrigerator malfunction in the field. However, freezing did not appear to affect the DOC or CDOM results, as seen from comparing DOC and CDOM data for samples from adjacent stations in the Maludam River that did and did not freeze.

Samples $(50-1000 \mathrm{~mL})$ for chlorophyll- $a$ were filtered onto pre-ashed $\left(450^{\circ} \mathrm{C}, 4 \mathrm{~h}\right) 25 \mathrm{~mm}$ diameter Whatman $\mathrm{GF} / \mathrm{F}$ filters, wrapped in aluminium foil, and immediately frozen in a liquid nitrogen dry shipper. They were stored in the dry shipper until analysis, within 6 months of collection.

Samples for total suspended solids (TSS, $50-1000 \mathrm{~mL}$ ) were filtered onto pre-ashed $\left(450^{\circ} \mathrm{C}, 4 \mathrm{~h}\right)$, pre-rinsed, preweighed $25 \mathrm{~mm}$ diameter Whatman GF/F filters. Filters were rinsed three times with DI water and stored at $-20^{\circ} \mathrm{C}$ in Petri dishes.

Procedural blanks for all parameters were prepared in the field using DI water.

\subsection{Chemical analyses}

\subsubsection{Dissolved organic carbon analysis}

Dissolved organic carbon was analysed as non-purgeable organic carbon on a Shimadzu TOC-L system with a high-salt combustion kit after a 5 min sparge, using potassium hydrogen phthalate for calibration. Instrument performance was monitored using certified deep-sea water from the Hansell Laboratory, University of Miami $\left(42-45 \mu \mathrm{mol} \mathrm{L}^{-1}\right)$. Our analyses consistently yielded slightly higher values for the reference water, with a long-term mean \pm 1 SD of $47 \pm$ $2.0 \mu \mathrm{mol} \mathrm{L}^{-1}(n=51)$. Procedural blanks prepared in the field almost all contained $<10 \mu \mathrm{mol} \mathrm{L}{ }^{-1}$, except for those prepared in between blackwater river samples, which contained $13-27 \mu \mathrm{mol} \mathrm{L}^{-1}$; a correction for these procedural blanks was not applied.

\subsubsection{Chromophoric dissolved organic matter analysis}

CDOM samples were warmed to room temperature and their absorbance measured from 230 to $900 \mathrm{~nm}$ against a DI water reference using a Thermo Evolution 300 dual-beam spectrophotometer. Samples from March were measured in either a 10 or a $1 \mathrm{~cm}$ pathlength quartz cuvette or in a $1 \mathrm{~cm}$ quartz cuvette after 10-fold dilution with DI water (for blackwaters). Samples from June and September were measured undiluted in either 10,1 , or $0.2 \mathrm{~cm}$ pathlength cuvettes. Instrument per- 

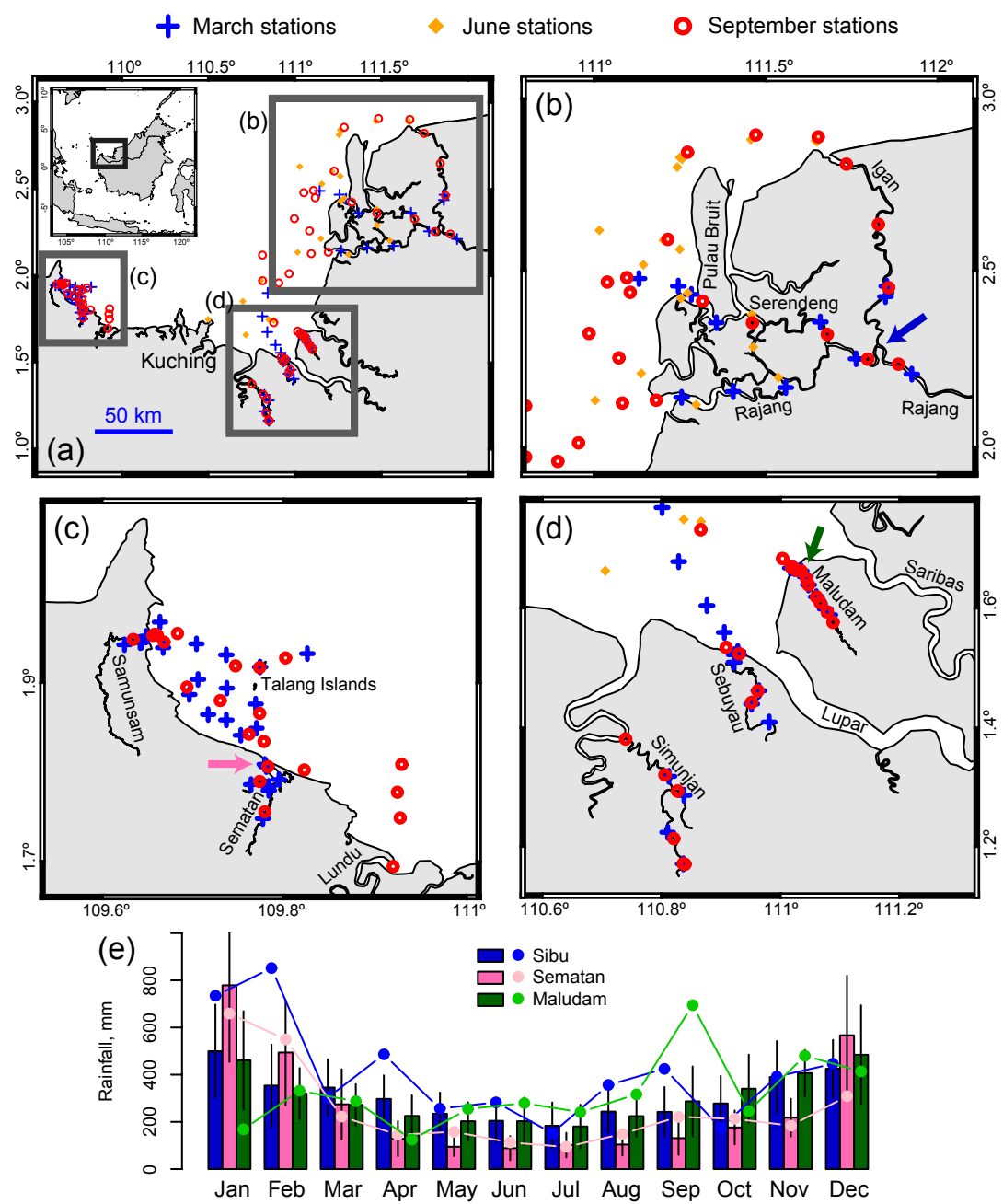

Figure 1. (a) Map of the study region showing station locations for each of the three expeditions. Thick grey boxes with letters indicate the areas shown in panels (b-d). (e) Monthly mean precipitation for the towns of Sibu, Sematan, and Maludam (locations of the rain gauges are marked with arrows in panels b, c, and d; arrow colours correspond to the bar colours in panel e). Bars show mean \pm 1 SD for 1999-2017, while points show values for 2017. Bars and points for the three locations in each month are separated horizontally for better readability but correspond to the same time periods.

formance was checked according to Mitchell et al. (2000). Reagent blanks of $\mathrm{NaN}_{3}$ in DI water were measured and subtracted from all samples. $\mathrm{NaN}_{3}$ was found to absorb significantly from 230 to $265 \mathrm{~nm}$, with decadic absorption coefficients of $\sim 26 \mathrm{~m}^{-1}$ at $230 \mathrm{~nm}, \sim 4 \mathrm{~m}^{-1}$ at $254 \mathrm{~nm}$ but $\leq 0.1 \mathrm{~m}^{-1}$ at wavelengths $\geq 275 \mathrm{~nm}$ (Supplement Fig. S1). Blank absorbances at wavelengths $\geq 275 \mathrm{~nm}$ were nearly always $<10 \%$ of sample absorbances, and mostly around $1 \%$ or less. CDOM spectra were baseline corrected (Green and Blough, 1994) and converted to Napierian absorption coefficients following Eq. (1):

$a_{\lambda}=2.303 \times \frac{A_{\lambda}}{l}$,

where $a_{\lambda}$ and $A_{\lambda}$ are respectively the absorption coefficient and the absorbance at wavelength $\lambda$, and $l$ is the cuvette pathlength in $\mathrm{m}$. These calculations were performed using the R package hyperSpec (Beleites and Sergo, 2018). Our raw CDOM spectra (as decadic absorption coefficients) are shown in Table S1, and representative spectra are shown in Fig. S2. CDOM spectral slope coefficients were calculated for the intervals $275-295$ and $350-400 \mathrm{~nm}$ using linear regression of log-transformed data as in Helms et al. (2008). Specific UV absorbance at $254 \mathrm{~nm}\left(\mathrm{SUVA}_{254}\right)$ was calculated from the decadic absorption coefficient at $254 \mathrm{~nm}$ and DOC concentration in $\mathrm{mg} \mathrm{L}^{-1}$. Dissolved inorganic constituents such as bromide, sulfide, nitrate, iodide, and molecular oxygen have negligible absorbance at wavelengths $\geq$ $250 \mathrm{~nm}$ compared to CDOM (Fally et al., 2000; Guenther et al., 2001). 

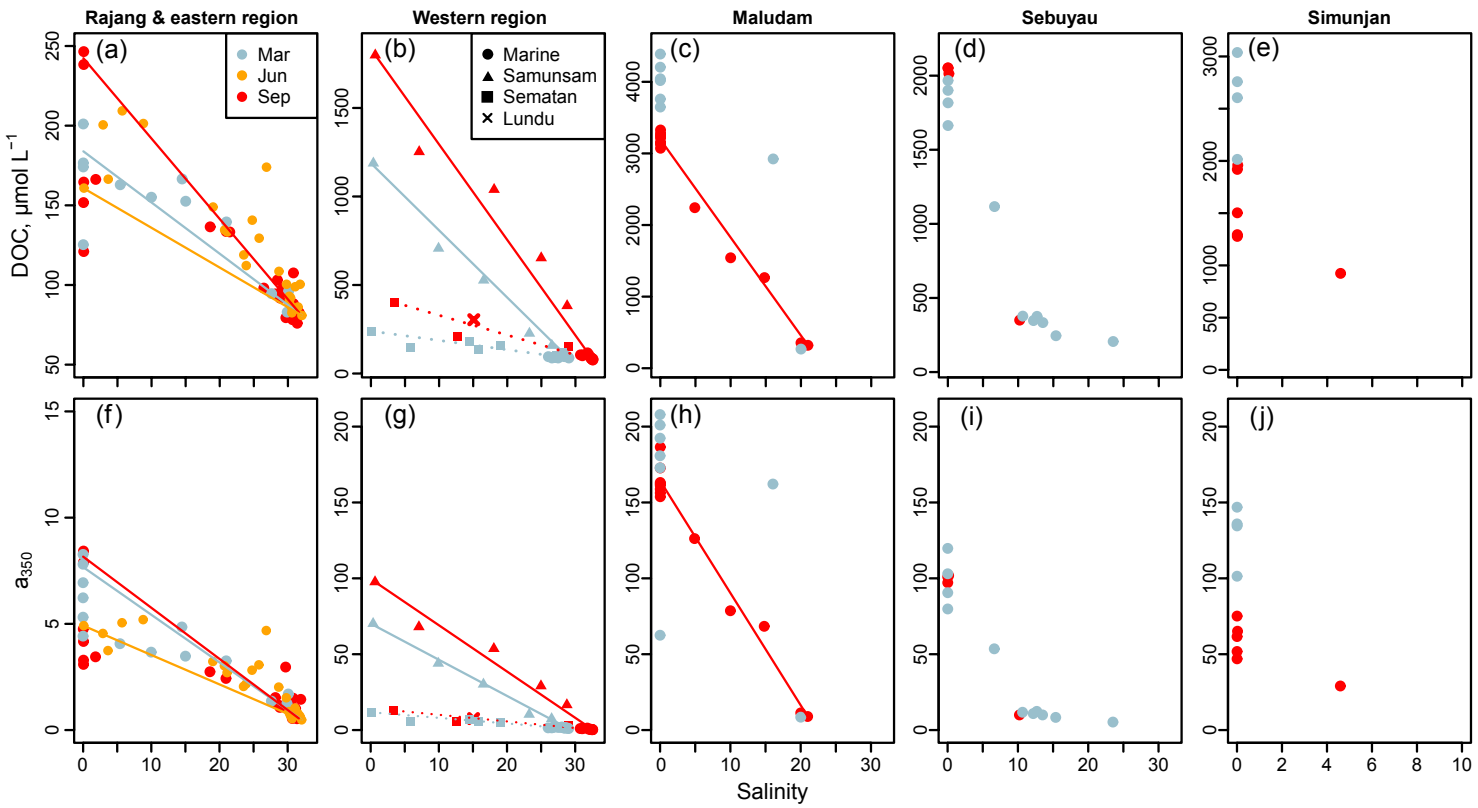

Figure 2. Changes in (a-e) dissolved organic carbon concentration and (f-j) $a_{350}$ from rivers to coastal seawater. Coloured lines show conservative mixing models for the data from the corresponding season. In $(\mathbf{b}, \mathbf{g})$, solid versus dashed lines distinguish the mixing models for the Sematan and Samunsam rivers in the western region. Data are separated by sampling region in columns, indicated by the column titles. Colours of plotting symbols are used to distinguish sampling seasons in all panels as per the legend in panel (a).

\subsubsection{Conservative mixing models for DOC and CDOM}

Two-endmember mixing models for DOC and CDOM were calculated for the Rajang, Samunsam, and Sematan rivers, and also for the Maludam River in September. For the other rivers and seasons, there was either insufficient variation in salinity (Maludam and Simunjan), or the salinity was influenced strongly by adjacent rivers that were not sampled (Sebuyau, which drains into the Lupar River estuary). Linear mixing models were calculated from the endmember DOC concentrations and CDOM spectra at salinity intervals of 1.0 from 0 salinity (river water) to the salinity of the marine endmember station (29-32.5). For CDOM, we calculated the full absorption spectrum at each interval and then recalculated the spectral slopes and $\mathrm{SUVA}_{254}$ values, following Stedmon and Markager (2003). It should be noted that conservative mixing of CDOM results in non-linear changes in spectral slopes and SUVA with salinity. Appropriate endmember stations were identified from salinity, DOC, and geographical location (Table S1). In March, rough seas prevented us from sampling fully marine waters in the eastern region, so the marine endmember station from the June expedition was used instead.

\subsubsection{Chlorophyll- $a$ and total suspended solids analysis}

Chlorophyll samples were extracted in $10 \mathrm{~mL} 90 \%$ acetone at $-20^{\circ} \mathrm{C}$ in the dark for $24 \mathrm{~h}$, and fluorescence measured at an excitation of $436 \mathrm{~nm}$ and emission of $680 \mathrm{~nm}$ (both with $5 \mathrm{~nm}$ bandpass) on a Horiba Fluoromax 4 spectrofluorometer (Welschmeyer, 1994). The fluorescence signal was normalised to the excitation lamp reference intensity and calibrated against a chlorophyll- $a$ standard from spinach (Sigma-Aldrich, C5753). The limit of detection (3 SD of the blank) was $<2$ ng chlorophyll per filter.

TSS samples were dried at $75^{\circ} \mathrm{C}$ for $24 \mathrm{~h}$ before reweighing. In March and September, they were then ashed at $450^{\circ} \mathrm{C}$ for 1 hour to remove organic matter and weighed again to determine inorganic weight. All weighing was performed on a Mettler-Toledo microbalance with $\pm 1 \mu \mathrm{g}$ accuracy.

\subsection{Photo-degradation experiments}

Four short-term photodegradation experiments were conducted in the field (one in June, three in September). For each, $1 \mathrm{~L}$ of sample water was filtered as for DOC and CDOM samples (using multiple Anodiscs if necessary), and filled into $150 \mathrm{~mL}$ acid-washed quartz bottles with ground quartz stoppers, leaving a headspace to prevent $\mathrm{O}_{2}$ limitation. Dark bottles were wrapped in aluminium foil and black plastic sheets. One dark and one light control bottle were filled with DI water and treated the same way as sample bottles to check for any systematic contamination (which was not found). All bottles were secured inside a clear, open, plastic food-storage container and exposed to natural sunlight on the roof of the boat (Rajang and seawater experiments) or in an open clearing on land (Samunsam experiment; incuba- 
tions were completely unaffected by shade between at least the hours of 08:00 and 16:00). To moderate the temperature during sun exposure, the container was filled with clear seawater to the same level as the samples in the bottles.

Experiments were run for 3-6 days. Solar radiation was monitored at varying intervals throughout each day with the reference irradiance sensor of a Trios RAMSES hyperspectral radiometer $(318-800 \mathrm{~nm}$ at $2 \mathrm{~nm}$ resolution). We integrated the measured irradiance from 318 to $450 \mathrm{~nm}$ (i.e. the portion of the spectrum with highest CDOM absorption) and then integrated this irradiance over time for each day, using exponential averaging to interpolate across measurement gaps to estimate the cumulative irradiance from 318 to $450 \mathrm{~nm}$, in $\mathrm{J} \mathrm{m}^{-2}$, to which samples were exposed throughout each experiment. This allowed us to account for differences in light intensity between days and between experiments by plotting the observed changes in DOM against actual irradiance instead of just as a function of time. However, owing to the large diameter and complex geometry of our quartz bottles, the diurnal change in sunlight angle, and the presence of the plastic container, we could not estimate absorbed light doses reliably enough to calculate apparent quantum yields of DOM photodegradation. We therefore used the estimated irradiances to help us to qualitatively understand how CDOM and DOC changed during sunlight exposure.

During the first three experiments, the radiometer was installed adjacent to the exposed samples and run throughout the experiments. During the experiment with Samunsam River water, the radiometer was in use on board the sampling boat while the samples were being exposed on land; however, there was only little cloud cover during those days, and this was evenly distributed across the land and sea. The Samunsam photodegradation experiment was then continued for an additional 3 days, during which no radiometer measurements could be taken. To estimate the approximate irradiances for these days, the amount of cloud cover on each day was noted, and radiometer measurements were taken from previous days that approximately matched the cloud conditions. The integrated irradiance for the Samunsam experiment is therefore less well constrained than for the other experiments, but since we are not attempting to quantitatively relate DOC degradation to absorbed photon dose, these uncertainties do not compromise our conclusions about the photolability of tDOM in Sarawak.

\section{Results}

\subsection{Concentrations of DOC}

Concentrations of DOC differed significantly between rivers, with highest freshwater concentrations (salinity $=0$ ) in the Maludam (3100-4400 $\mu \mathrm{mol} \mathrm{L}^{-1}$ ), and lowest concentrations in the Rajang (120-250 $\mu \mathrm{mol} \mathrm{L}^{-1}$ ) (Fig. 2a-e). Seasonal differences were clearly apparent in the river samples but did not show a consistent direction: the Sematan and Samunsam rivers carried $\geq 50 \%$ higher DOC concentrations in September than in March, the Sebuyau River had marginally higher concentrations in September than in March, while the Maludam and Simunjan rivers had 20\%-40\% lower DOC concentrations in September than in March. Seasonality in the Rajang River is not apparent in Fig. 2a, possibly because of variability between distributary channels.

In March, DOC concentrations at freshwater stations in the Maludam and Sebuyau increased with distance downstream but decreased slightly in the Simunjan (Fig. 3a-c). In September, DOC concentrations varied little with distance downstream in these three blackwater rivers (Fig. 3ac). In the Rajang River, DOC concentrations at 0 salinity in each individual channel were somewhat higher in March than in September (Fig. 3g-i; June data are not shown because only one station had 0 salinity in June). Notably, DOC concentrations in the Rajang Delta increased substantially with distance downstream in each of the distributary channels (Fig. 3g-i), with concentrations doubling to around $240 \mu \mathrm{mol} \mathrm{L}{ }^{-1}$ during passage through the northernmost distributary, the Igan.

DOC concentrations decreased with increasing salinity in all river estuaries (Fig. 2a-e). In the Samunsam, Sematan, and Maludam rivers this decrease closely followed the predictions from a two-endmember mixing model, with the single sample from the Lundu River being plotted very close to the Sematan mixing model. For the Sebuyau River, a conservative mixing model could not be constructed because it discharges into the estuary of the larger Lupar River (Fig. 1), for which the freshwater endmember DOC concentration was not measured. For the Simunjan River and for the Maludam River in March too few data from brackish waters were available to construct a reliable mixing model.

In contrast, the DOC concentrations in the Rajang Delta do not fit the conservative mixing models well: most of the March and June data from brackish stations have higher DOC concentrations than expected and in fact are closer to predictions from the September mixing model (Fig. 2a). The September mixing model was calculated as the freshwater endmember using the DOC concentration of the two northernmost stations in the Igan distributary, which had the highest DOC concentrations of any of the Rajang River stations.

Some seasonality in DOC concentration was seen at the stations furthest offshore, which had the highest salinities (29.0-32.5). This was most evident in the western region: in March, the stations with highest salinities (28.9 and 29.0) contained 93 and $87 \mu \mathrm{mol} \mathrm{L}^{-1}$ DOC, while in September the same stations had 76 and $78 \mu \mathrm{mol} \mathrm{L}{ }^{-1} \mathrm{DOC}$, and salinities $>32.0$. In the eastern region, the highest offshore salinities in June were 30.2-32.1 with DOC concentrations of 81$99 \mu \mathrm{mol} \mathrm{L}^{-1}$, while in September the DOC concentrations were lower at $76-83 \mu \mathrm{mol} \mathrm{L}^{-1}$ with salinities of $29.7-31.6$ (except for one station with $88 \mu \mathrm{mol} \mathrm{L}^{-1} \mathrm{DOC}$ ). 

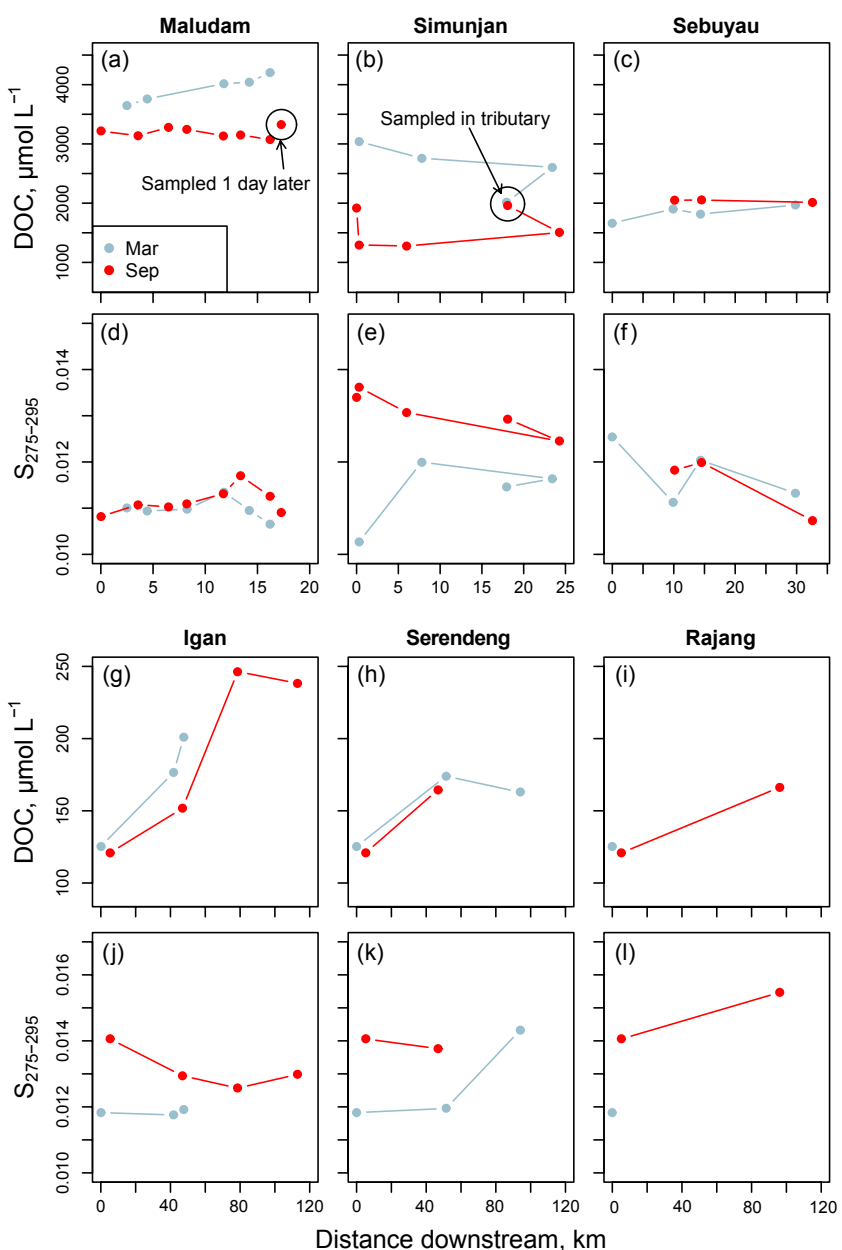

Figure 3. Changes in (a-c) and (g-i) dissolved organic carbon concentration and (d-f) and (j-l) $S_{275-295}$ with distance downstream for all stations with salinity of 0 . Data in (a-f) are for the Maludam, Simunjan, and Sebuyau rivers, while (g-l) show data for the three main Rajang distributaries (named in Fig. 1b): panels (h, k) show data for the Serendeng branch (includes the Lebaan and Paloh sections), while panels (i, I) show data for the Rajang branch (includes the Payang section).

\subsection{Spectral characteristics of CDOM}

\subsubsection{CDOM absorption coefficient}

CDOM concentrations, quantified as $a_{350}$, were high throughout our study region. Nearly all samples in the blackwater rivers had $a_{350}$ values $>50 \mathrm{~m}^{-1}$, with samples from the Maludam reaching $210 \mathrm{~m}^{-1}$ (Fig. $2 \mathrm{f}-\mathrm{j}$ ). Lower values were found in the Rajang and Sematan rivers, between 3 and $11 \mathrm{~m}^{-1}$. The lowest $a_{350}$ value $\left(0.23 \mathrm{~m}^{-1}\right)$ was found in the furthest offshore station in the western region in September. The mixing behaviour of $a_{350}$ closely mirrored that of DOC in each of the rivers (Fig. 2).

\subsubsection{Spectral slopes}

The CDOM spectral slope from 275 to $295 \mathrm{~nm}\left(S_{275-295}\right)$ was low in all freshwater samples, ranging from 0.0102 to 0.0144 , and increased with salinity to a maximum of 0.0254 (Fig. 4ae). $S_{275-295}$ was somewhat lower in most of the blackwater samples (Samunsam, Maludam, Sebuyau, and Simunjan) than in the Rajang and Sematan. Seasonal differences were clearly seen in the marine samples in the western region, with $S_{275-295}$ always below 0.0200 in March but up to 0.0254 in September (Fig. 4b). In the Rajang distributaries, $S_{275-295}$ was lower in March than in September (Fig. 3j-1), but no clear seasonality was seen in the eastern region marine samples (Fig. 4a), although we were unable to collect many marine samples in March due to rough seas.

In the Samunsam and Maludam rivers, $S_{275-295}$ closely followed the conservative mixing models, but this was not the case in the Rajang and the Sematan rivers (Fig. 4ac). In the Rajang, samples at salinities 3-20 typically had higher $S_{275-295}$ than predicted by the mixing models (except in June), while many samples at salinities $>20$ had $S_{275-295}$ values that were lower than predicted by the mixing models. Similarly, in the Sematan River in March, samples in brackish water up to salinity 20 showed higher $S_{275-295}$ than expected from conservative mixing. In September, we were unable to sample fully freshwater in the Sematan River owing to the timing of the tides, so the freshest sample still had a salinity of 3.4 and may therefore have already been affected by any non-conservative processes in the estuary. However, all samples in the western region with salinities $>25$ fell very closely between the conservative mixing lines for the Sematan and Samunsam rivers.

The spectral slope from 350 to $400 \mathrm{~nm}\left(S_{350-400}\right)$ showed more complex trends: freshwater samples had values mostly between 0.014 and 0.018 , while brackish and fully marine waters spanned a greater range of 0.0076-0.0206 (Fig. 4fj). The marine endmember stations in the eastern and western regions both had lower $S_{350-400}$ than the river endmembers in September but had higher values (western region) or nearly identical values (eastern region) in March and June. In the Rajang and Sematan rivers, $S_{350-400}$ showed conservative mixing up to salinities of $20-25$ but was lower than predicted by conservative mixing in the blackwater Samunsam and Maludam rivers (Fig. 4f-h). At salinities $>20-25$, many samples clearly depart from the conservative mixing models, except for samples in March in both regions.

However, the spectral slope ratio, $S_{\mathrm{R}}$ (the ratio of $S_{275-295}$ to $S_{350-400}$ ), showed trends very similar to $S_{275-295}$, i.e. low values in river waters $(0.601-0.867)$ and higher values in marine waters with salinity $>25(0.786-2.33$; Fig. $4 k-0)$. In brackish waters, $S_{\mathrm{R}}$ was typically slightly greater than predicted by the conservative mixing models, especially in March in the Rajang, Sematan, and Samunsam rivers, and in September in the Rajang, Samunsam, and Maludam rivers (Fig. 4k-m). 

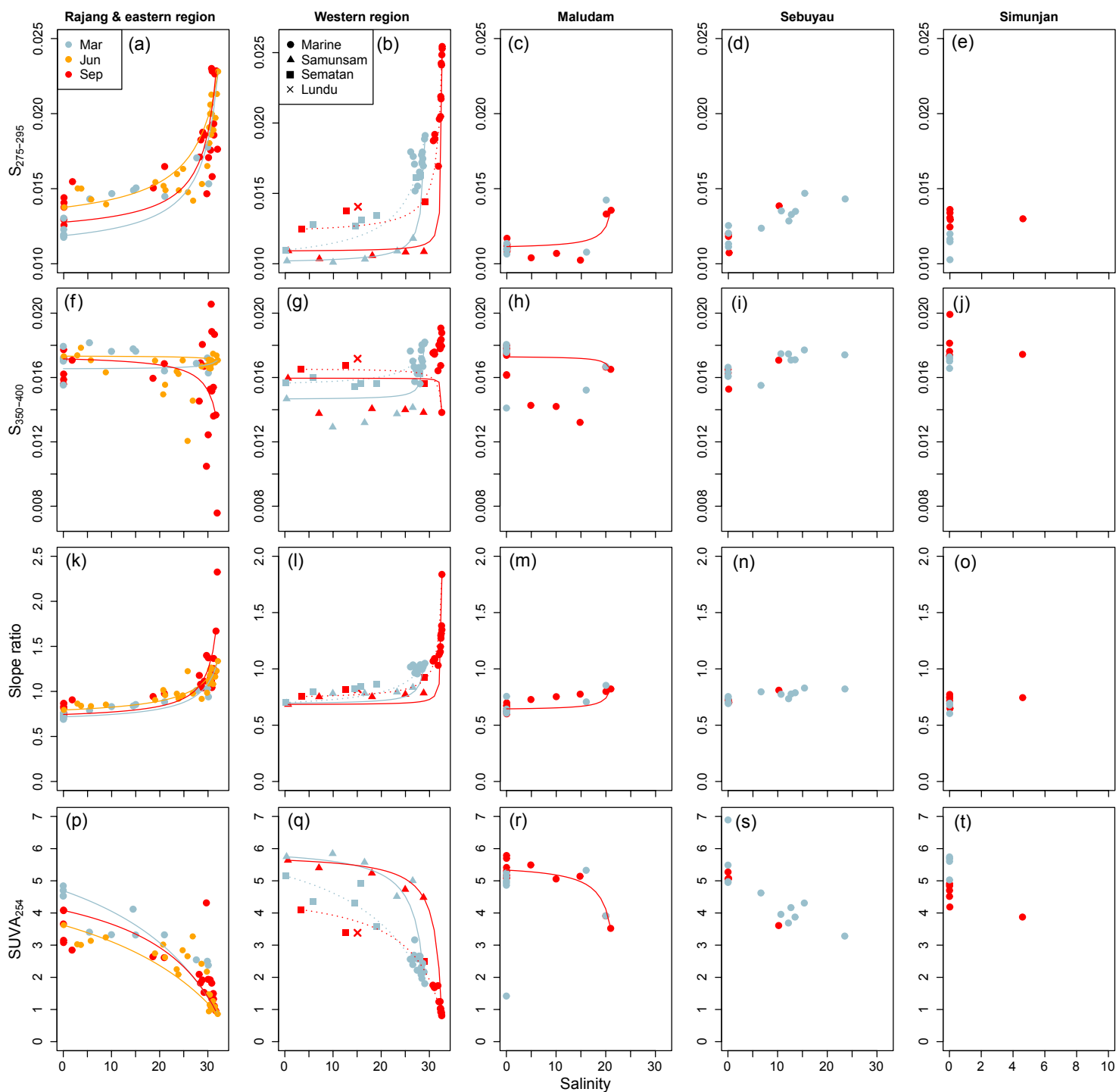

Figure 4. Changes in (a-e) $S_{275-295}$, (f-j) $S_{350-400}$, (k-o) CDOM spectral slope ratio, and (p-t) SUVA 254 from rivers to coastal seawater. Conservative mixing lines are shown as in Fig. 2 (note that conservative mixing of CDOM properties is non-linear). Data are shown separately for each sampling region as indicated by column titles.

\subsubsection{Specific UV absorbance}

The specific UV absorbance at $254 \mathrm{~nm}\left(\mathrm{SUVA}_{254}\right)$ was higher in river samples (3.08-6.89 at salinity 0) than in marine samples ( $0.81-5.00$ at salinity $>25)$, and decreased with salinity for all rivers and seasons (Fig. 4p-t). SUVA 254 was somewhat higher in the Rajang and in the Simunjan in March than in June or September, but otherwise seasonal differences in the rivers were not pronounced. However, as for the other CDOM parameters, there was a clear difference between March and September in the marine samples from the western region (Fig. 4q). The data from the Maludam, Sematan, and Samunsam rivers closely followed the conservative mixing lines, while in the Rajang, the majority of brack- ish samples with salinity $>20$ showed somewhat greater $\mathrm{SUVA}_{254}$ than expected from conservative mixing (Fig. $4 \mathrm{p}-$ r). Because sodium azide contributes a relatively high blank absorbance at $254 \mathrm{~nm}$ but not beyond $270 \mathrm{~nm}$, we compared our $\mathrm{SUVA}_{254}$ values to the specific UV absorbance at $280 \mathrm{~nm}, \mathrm{SUVA}_{280}$ for each sample. We found a very strong, linear relationship between $\mathrm{SUVA}_{280}$ and $\mathrm{SUVA}_{254}$ for the entire data set across rivers and seasons, with $\mathrm{SUVA}_{280}=$ $0.792 \times$ SUVA $_{254}-0.0141\left(r^{2}=0.990, p<0.001, n=154\right)$, suggesting that our $\mathrm{SUVA}_{254}$ measurements were not compromised by the $\mathrm{NaN}_{3}$ blank $\left(\mathrm{NaN}_{3}\right.$ has no absorbance at 280 nm, Fig. S1). 

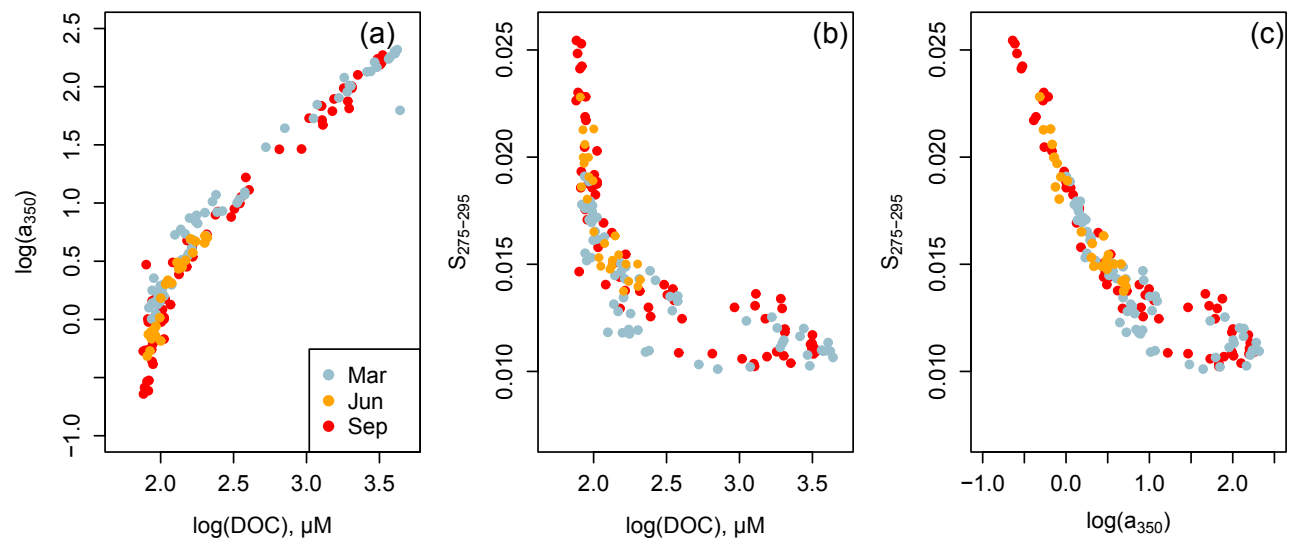

Figure 5. Scatter plots of (a) CDOM absorption versus DOC concentration, (b) $S_{275-295}$ versus DOC concentration, and (c) $S_{275-295}$ versus CDOM absorption for the entire data set. Strong relationships were found between these parameters but without seasonal variation.

\subsubsection{Relationships between DOC and CDOM}

The CDOM concentration, as $a_{350}$, was closely related to the DOC concentration for the entire data set (Fig. 5a). $S_{275-295}$ was also strongly related to DOC, though with somewhat greater scatter at DOC concentrations greater than about $150 \mu \mathrm{mol} \mathrm{L}^{-1}$ (Fig. 5b). Consequently, there was also a strong relationship between $S_{275-295}$ and $a_{350}$, although also with more scatter wherever $a_{350}>10 \mathrm{~m}^{-1}$ (Fig. 5c). The increased scatter in Fig. 5b, $c$ at high DOC and CDOM concentrations is due to the fact that the rivers differed somewhat in $S_{275-295}$ : in particular, the Rajang, Sematan, and Simunjan had higher $S_{275-295}$ for a given DOC or CDOM concentration than the Samunsam and Maludam. There was no seasonal variation in any of these relationships, inasmuch as the data sets from all three seasons plot along a single trajectory in all three plots rather than segregating into parallel trajectories by season.

\subsection{Photodegradation of DOC and CDOM}

DOM from the Rajang and Samunsam rivers was photolabile, with DOC and CDOM decreasing after sunlight exposure. In contrast, marine water collected in the eastern region only showed some changes in CDOM but no decrease in DOC (Fig. 6, Table 1). Daily irradiances, integrated from 318 to $450 \mathrm{~nm}$, ranged from 0.92 to $3.00 \mathrm{MJ} \mathrm{m}^{-2}$, with cumulative irradiances for each experiment ranging from 5 to $11 \mathrm{MJ} \mathrm{m}^{-2}$. Irradiance data for each day are shown in Fig. S3. In practice, plotting our data against estimated cumulative irradiance showed the same trends as simply plotting against time of exposure (Fig. S4), although we estimate that the Samunsam water received a slightly higher irradiance over 5 days than the marine water over 6 days and that the two Rajang experiments differed by about $20 \%$ in irradiance despite both lasting 3 days.

The Rajang water in June lost $16.1 \pm 0.5 \mu \mathrm{mol} \mathrm{L}{ }^{-1}$ DOC by the end of the experiment (mean $\pm 1 \mathrm{SD}$, represent- ing $8.8 \%-9.4 \%$ of the starting DOC), with $a_{350}$ decreasing as well. $S_{275-295}$ and $S_{\mathrm{R}}$ both increased, while $S_{350-400}$ remained essentially unchanged, and $\mathrm{SUVA}_{254}$ decreased slightly (Fig. 6). In September, we found very similar changes in the Rajang water after sunlight exposure: $18.9 \pm$ $6.1 \mu \mathrm{mol} \mathrm{L}{ }^{-1}$ DOC were lost (mean $\pm 1 \mathrm{SD}$, representing $5.6 \%-10.7 \%$ of starting DOC), $a_{350}$ decreased, and $S_{275-295}$ and $S_{\mathrm{R}}$ increased by amounts similar to June. Although $S_{350-400}$ decreased slightly relative to the initial sample, there was no difference between light and dark bottles in this parameter. SUVA 254 decreased slightly in the light bottles and actually increased somewhat in the dark bottles. Marine water showed no change in DOC upon light exposure, although light bottles had very slightly higher DOC concentrations than dark bottles at the end of the experiment (by $4.5-6.1 \mu \mathrm{mol} \mathrm{L}^{-1}$ ). However, light bottles had lower $a_{350}$ than dark bottles at the end of the experiment, and $S_{275-295}$ increased strongly due to light exposure, reaching values higher than seen in any of our environmental samples (>0.030). $S_{350-400}$ increased both in light and dark bottles relative to the initial sample, and $S_{\mathrm{R}}$ consequently dropped in the dark bottles but remained relatively constant in the light bottles. $\mathrm{SUVA}_{254}$ decreased slightly after light exposure. The greatest effects of photodegradation were seen in the Samunsam River blackwater, with a decrease in DOC by $432 \pm 42 \mu \mathrm{mol} \mathrm{L}^{-1}$ (mean $\pm 1 \mathrm{SD}$, representing $21 \%$ $26 \%$ of initial DOC) and a large reduction in $a_{350} . S_{275-295}$ and $S_{\mathrm{R}}$ both increased, $S_{350-400}$ decreased, but $\mathrm{SUVA}_{254}$ remained essentially unchanged (Fig. 6). Notably, DOC and $a_{350}$ showed a linear decrease with cumulative irradiance in all three river water experiments, suggesting that more DOC could have been mineralised (and more CDOM lost) if sunlight exposure had continued. 

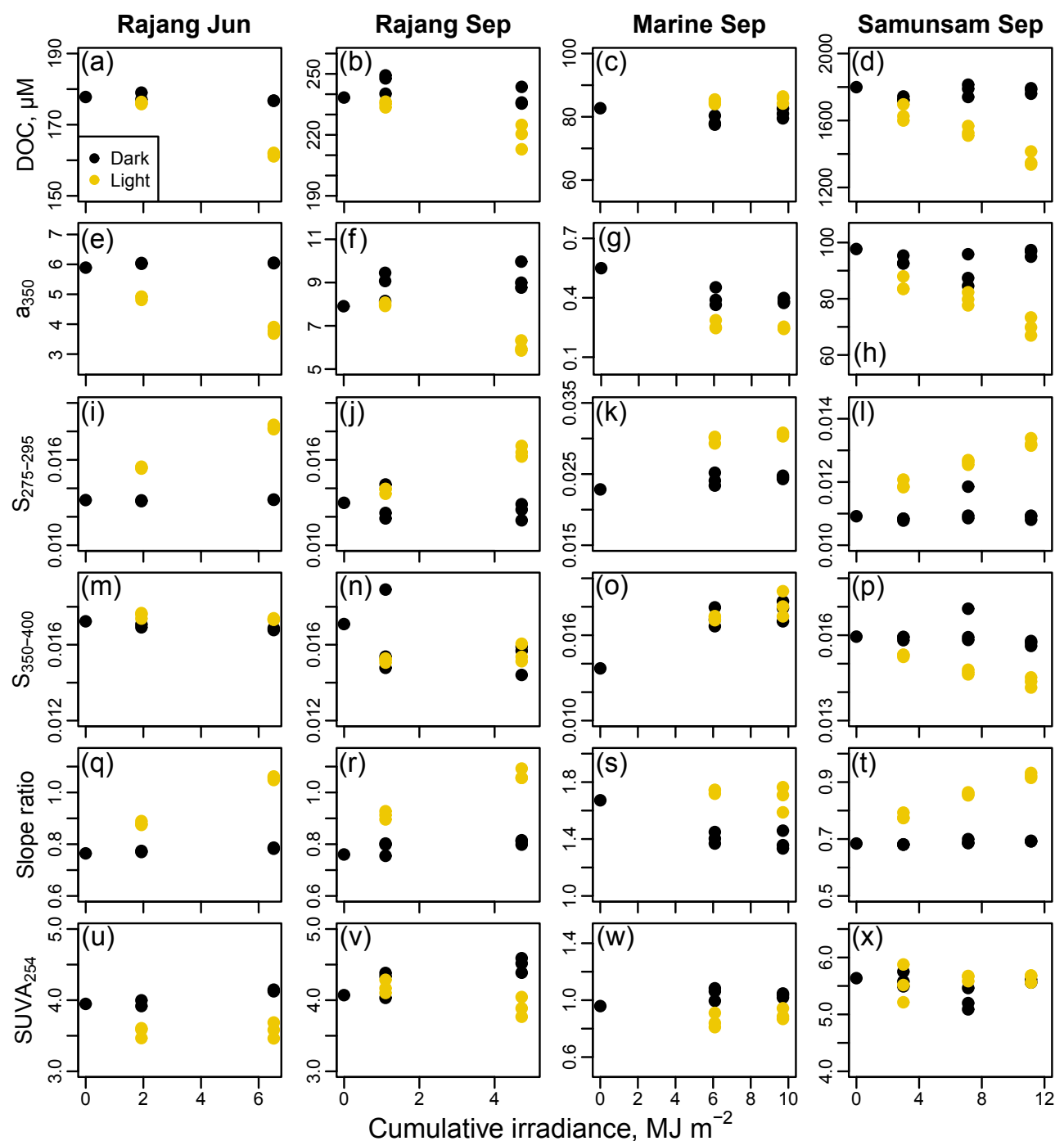

Figure 6. Results from photodegradation experiments showing the decrease in DOC (a-d), CDOM concentration (e-h), $S_{275-295}(\mathbf{i}-\mathbf{l})$, $S_{350-400}(\mathbf{m}-\mathbf{p})$, CDOM spectral slope ratio $(\mathbf{q}-\mathbf{t})$, and SUVA $_{254}(\mathbf{u}-\mathbf{x})$ with cumulative irradiance from 318 to $450 \mathrm{~nm}$ in wavelength. Each column corresponds to one degradation experiment, as indicated in the column titles. Black symbols indicate dark control bottles; yellow symbols indicate light-exposed bottles.

\subsection{Distributions of chlorophyll- $a$ and suspended sediments}

Chlorophyll- $a$ concentrations were mostly $<3 \mu g \mathrm{~L}^{-1}$

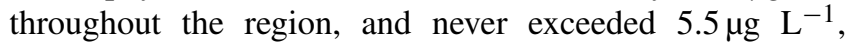
indicating quite oligotrophic conditions (Fig. 7a-e). Concentrations in the rivers at salinity 0 were always $<1 \mu \mathrm{g} \mathrm{L}-1$ except in the Simunjan (up to $3.8 \mu \mathrm{g} \mathrm{L}^{-1}$ ), and higher values were generally found in the estuaries at salinities between 10 and 25 .

Total suspended solids in the Rajang reached values up to nearly $400 \mathrm{mg} \mathrm{L}^{-1}$, with values in the brackish waters of the Rajang Delta varying mostly between 10 and $70 \mathrm{mg} \mathrm{L}^{-1}$ (Fig. $7 \mathrm{f}-\mathrm{i}$ ). More than $90 \%$ by weight of this material was inorganic. The other rivers and the most distant marine samples all contained far lower TSS concentrations, but the estuaries always had $>10 \mathrm{mg} \mathrm{L}^{-1}$.

\section{Discussion}

\subsection{Distribution of DOM within and between rivers}

Rivers in Sarawak clearly differ substantially in their DOM concentrations. All of the blackwater rivers had DOC concentrations above $1200 \mu \mathrm{mol} \mathrm{L}^{-1}$, with highest values in the Maludam River. These results are consistent with previous measurements in the Maludam (Müller et al., 2015), and in other blackwater rivers in South-East Asia (Alkhatib et al., 2007; Cook et al., 2017; Harun et al., 2016; Moore et 

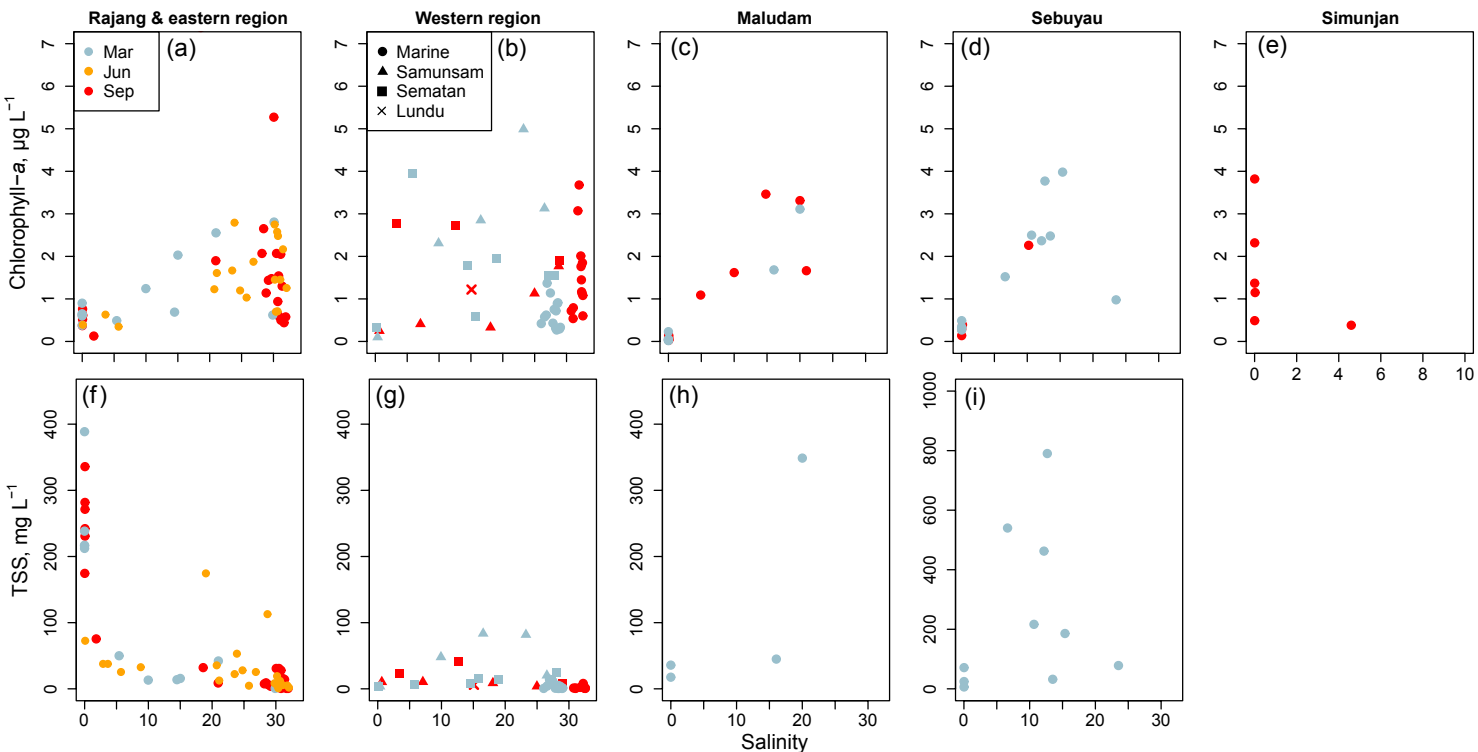

Figure 7. Distribution of (a-e) chlorophyll- $a$, and (f-i) total suspended solids from rivers to coastal seawater for each study region. TSS was not measured in the Simunjan.

al., 2011; Rixen et al., 2008; Wit et al., 2015), but they are high compared to DOC measurements in blackwaters from other continents, which are typically below $2000 \mu \mathrm{mol} \mathrm{L}-1$ (Lawrenz et al., 2010; Leech et al., 2016). The Maludam, Sebuyau, and Simunjan rivers drain peatlands along most of their catchments (Müller et al., 2016), while the Samunsam River drains an extensive area of peatland in its upper reaches. The lower DOC concentrations in the Rajang, Sematan, and Lundu rivers are closer to concentrations reported from the Lupar and Saribas (mostly $<500 \mu \mathrm{mol} \mathrm{L}^{-1}$ ), the two larger rivers that flank the Maludam peat dome (Fig. 1) (Müller et al., 2016). The Rajang River drains mineral soils along most of its catchment, and peatlands (up to several metres thick) are only found in the delta surrounding the distributaries (Gastaldo, 2010; Staub et al., 2000). The Sematan and Lundu river catchments also have at most limited peat deposits. The pronounced increase in DOC concentration with distance downstream in the three main Rajang distributary channels clearly shows that there are large organic matter inputs into the distributaries. Chlorophyll- $a$ concentrations in the Rajang were very low, and no traces of aquatic macrophytes were seen in any of the rivers; given the very low light penetration due to suspended sediments and CDOM (see Sect. 4.3.2), benthic primary production is likely to be at most minimal. We therefore rule out a significant autochthonous DOC source. Bacterial solubilisation of particulate organic carbon (POC) is a possible in situ source of DOC, but our CDOM data did not indicate a substantial bacterial DOM source (see Sect. 4.4). Photochemical POC solubilisation could also produce DOC in situ (Kieber et al., 2006; Mayer et al., 2006). However, estimated rates of photochemical POC solubilisation under realistic condi- tions of light penetration are only around $4-6 \mathrm{mmol} \mathrm{m}^{-2} \mathrm{~d}^{-1}$ (Kieber et al., 2006; Riggsbee et al., 2008), which is too low to explain the DOC increase we observed, given the likely short transit time of water through the Rajang Delta (see Sect. 4.3.2). Instead, the DOC input most likely originates from the peatlands in the delta. Peatlands are found throughout the delta but are most extensive and deep along the Igan distributary (Gastaldo, 2010; Staub et al., 2000), and the Igan also showed the greatest increase in DOC with distance downstream of all the Rajang distributaries, consistent with our hypothesis of a peatland DOM source to the Rajang Delta. However, future work should explicitly address the possibility of POM solubilisation to DOM in South-East Asian rivers.

None of the river catchments consist of genuinely pristine peat swamps: much of the peatland surrounding the Simunjan, Sebuyau, and Rajang rivers has been converted to oil palm plantations, and even the less impacted Maludam and Samunsam catchments have been disturbed to some degree by logging. Human disturbance has been shown to increase the loss of DOC from peatlands at field sites in central Borneo (Moore et al., 2013), and depending on water table height, peatland oil palm plantations in Sarawak can also export old DOC (Cook et al., 2018). Differences in DOM quality between agricultural and natural peatland sites on Borneo have also been noted (Harun et al., 2016; Materić et al., 2017). While it is thus clear that land use can impact DOC export from South-East Asian peatlands, our study was not designed specifically to determine the effect of land use on DOM concentrations or quality in the rivers; more field work would be needed to do so. 
Table 1. Summary of results from photodegradation experiments for DOC, $S_{275-295}$, and CDOM concentration $\left(a_{350}\right)$. All values are mean \pm SD for each treatment. Day 0 data are the values measured at the corresponding station from which water for each experiment was taken. All irradiance data are in Joules $\mathrm{m}^{-2}$, integrated from 318 to $450 \mathrm{~nm}$.

\begin{tabular}{|c|c|c|c|c|c|c|c|}
\hline \multicolumn{8}{|c|}{ Rajang experiment June } \\
\hline & Cumulative irradiance & \multicolumn{2}{|c|}{ DOC, $\mu \mathrm{mol} \mathrm{L}^{-1}$} & \multicolumn{2}{|c|}{$S_{275-295}$} & \multicolumn{2}{|c|}{$a_{350}$} \\
\hline Day & & Light & Dark & Light & Dark & Light & Dark \\
\hline 0 & 0 & \multicolumn{2}{|c|}{178} & \multicolumn{2}{|c|}{0.0132} & \multicolumn{2}{|c|}{5.89} \\
\hline 1 & $1.93 \times 10^{6}$ & $176 \pm 0.31$ & $178 \pm 1.34$ & $0.0155 \pm 6.4 \times 10^{-5}$ & $0.0131 \pm 3.5 \times 10^{-5}$ & $4.88 \pm 0.06$ & $6.03 \pm 0.02$ \\
\hline 3 & $6.53 \times 10^{6}$ & $162 \pm 0.51$ & $177 \pm 0.07$ & $0.0183 \pm 1.6 \times 10^{-4}$ & $0.0132 \pm 6.3 \times 10^{-6}$ & $3.79 \pm 0.11$ & $6.05 \pm 0.02$ \\
\hline \multicolumn{8}{|c|}{ Rajang experiment September } \\
\hline & Cumulative irradiance & \multicolumn{2}{|c|}{$\mathrm{DOC}, \mu \mathrm{mol} \mathrm{L}{ }^{-1}$} & \multicolumn{2}{|c|}{$S_{275-295}$} & \multicolumn{2}{|c|}{$a_{350}$} \\
\hline Day & & Light & Dark & Light & Dark & Light & Dark \\
\hline 0 & 0 & \multicolumn{2}{|c|}{238} & \multicolumn{2}{|c|}{0.0130} & \multicolumn{2}{|c|}{7.91} \\
\hline 1 & $1.10 \times 10^{6}$ & $235 \pm 1.4$ & $246 \pm 4.8$ & $0.0138 \pm 2.0 \times 10^{-4}$ & $0.0128 \pm 1.3 \times 10^{-4}$ & $8.00 \pm 0.08$ & $8.89 \pm 0.67$ \\
\hline 3 & $4.72 \times 10^{6}$ & $219 \pm 6.1$ & $238 \pm 4.6$ & $0.0166 \pm 3.7 \times 10^{-4}$ & $0.0124 \pm 5.8 \times 10^{-4}$ & $6.04 \pm 0.25$ & $9.24 \pm 0.64$ \\
\hline \multicolumn{8}{|c|}{ Marine experiment September } \\
\hline & Cumulative irradiance & \multicolumn{2}{|c|}{$\mathrm{DOC}, \mu \mathrm{mol} \mathrm{L}-1$} & \multicolumn{2}{|c|}{$S_{275-295}$} & \multicolumn{2}{|c|}{$a_{350}$} \\
\hline Day & & Light & Dark & Light & Dark & Light & Dark \\
\hline 0 & 0 & \multicolumn{2}{|c|}{83} & \multicolumn{2}{|c|}{0.0228} & \multicolumn{2}{|c|}{0.55} \\
\hline 4 & $6.08 \times 10^{6}$ & $85 \pm 0.8$ & $79 \pm 1.6$ & $0.0299 \pm 5.2 \times 10^{-4}$ & $0.0242 \pm 9.1 \times 10^{-4}$ & $0.261 \pm 0.022$ & $0.402 \pm 0.045$ \\
\hline 6 & $9.71 \times 10^{6}$ & $86 \pm 1.2$ & $81 \pm 1.6$ & $0.0306 \pm 2.5 \times 10^{-4}$ & $0.0245 \pm 2.3 \times 10^{-4}$ & $0.247 \pm 0.006$ & $0.385 \pm 0.012$ \\
\hline \multicolumn{8}{|c|}{ Samunsam experiment September } \\
\hline & Cumulative irradiance & \multicolumn{2}{|c|}{ DOC, $\mu \mathrm{mol} \mathrm{L}^{-1}$} & \multicolumn{2}{|c|}{$S_{275-295}$} & \multicolumn{2}{|c|}{$a_{350}$} \\
\hline Day & & Light & Dark & Light & Dark & Light & Dark \\
\hline 0 & 0 & \multicolumn{2}{|c|}{1799} & \multicolumn{2}{|c|}{0.0109} & \multicolumn{2}{|c|}{97.6} \\
\hline 1 & $2.99 \times 10^{6}$ & $1640 \pm 50$ & $1730 \pm 11$ & $0.0119 \pm 1.3 \times 10^{-4}$ & $0.0108 \pm 3.2 \times 10^{-5}$ & $85.0 \pm 2.6$ & $93.5 \pm 1.5$ \\
\hline 3 & $7.13 \times 10^{6}$ & $1535 \pm 30$ & $1781 \pm 38$ & $0.0126 \pm 7.0 \times 10^{-5}$ & $0.0112 \pm 5.6 \times 10^{-4}$ & $79.9 \pm 2.3$ & $89.2 \pm 5.9$ \\
\hline 5 & $11.2 \times 10^{6}$ & $1366 \pm 42$ & $1779 \pm 17$ & $0.0133 \pm 1.2 \times 10^{-4}$ & $0.0109 \pm 7.1 \times 10^{-5}$ & $70.0 \pm 3.2$ & $96.4 \pm 1.2$ \\
\hline
\end{tabular}

Our CDOM data show that all rivers were characterised by high levels of tDOM, with the blackwater rivers in particular having extremely high absorption coefficients, very low $S_{275-295}$, and high SUVA 254 . $S_{275-295}$ is now well established as an optical tracer for tDOC in estuarine and marine waters (Fichot and Benner, 2011, 2012; Helms et al., 2008) and is inversely related to the mean molecular weight of DOM in a sample (Helms et al., 2008). SUVA 254 is positively related to the aromaticity of DOM (Traina et al., 1990; Weishaar et al., 2003). Our values for $S_{275-295}$ and $\mathrm{SUVA}_{254}$ in the rivers are respectively on the low and the high end of values reported from other freshwaters, especially in our blackwater rivers (Fichot and Benner, 2014; Helms et al., 2008; Leech et al., 2016; Massicotte et al., 2017). These river systems in Sarawak are therefore characterised by DOM with high average molecular weight and high aromaticity, consistent with a terrigenous rather than aquatic source. Moreover, even the clearest marine waters that we sampled had $S_{275-295}$ no greater than about 0.025 , which is consistent with some of the DOM in these waters having a terrigenous origin.

Riverine DOC concentrations do not always show a simple relationship with precipitation and river discharge, especially in peatland-draining rivers (Clark et al., 2007). Previous DOC measurements in the Saribas and Lupar rivers in Sarawak did not show consistent seasonality (Müller et al., 2016). Our data indicate that DOC concentrations at the end of the wettest season (March) were higher than at the end of the drier season (September) in the Rajang, Maludam, and Simunjan rivers but by different amounts. In contrast, the Samunsam, Sematan, and Sebuyau showed lower concentrations in March than in September but again by different amounts between the rivers. These differences between rivers probably reflect differences in catchment hydrology rather than variation in weather conditions, given that precipitation in 2017 was mostly close to the 18 -year mean. However, the Maludam experienced unusually high precipitation in September, with nearly all of the excess precipitation rela- 
tive to the mean falling during two consecutive days and less than 1 week before our sampling. It is possible that this high precipitation could have had a dilution effect (Clark et al., 2007) and contributed to the lower September DOC concentrations in this river. Because the Maludam is a very small river, the precipitation record from Maludam village is likely to reflect rainfall across the Maludam catchment. This is unlikely to be the case for the Rajang River; therefore, the elevated February precipitation in Sibu would probably not have affected our March data for the Rajang.

Overall, our data clearly show that there is inconsistent seasonality in riverine DOC concentrations across Sarawak, while precipitation is relatively high year-round. Sarawak is thus clearly characterised by high tDOC fluxes to sea in all seasons, as reflected by the low $S_{275-295}$ values at all of our marine stations. Nevertheless, we found a stronger terrigenous signal during the north-east monsoon in the western region marine samples, although we cannot say whether this reflects a seasonal change in the magnitude of the tDOC flux to sea or perhaps a seasonal difference in the degradation rate of tDOC at sea. For example, rougher, more turbid seas and greater cloud cover during the north-east monsoon might reduce the solar irradiance underwater and thus reduce the rate of photodegradation.

Despite the fact that there are large differences in CDOM concentration and some differences in CDOM spectral properties between rivers, we found very strong relationships between DOC concentration, $a_{350}$, and $S_{275-295}$ across our entire data set. Unlike, for example, in the northern Gulf of Mexico (Fichot and Benner, 2011), there was no seasonal variability in these relationships. This suggests that there are no strong seasonal changes in tDOM composition within our study region, despite the seasonal concentration differences discussed above.

\subsection{Photolability of riverine DOM}

Our experiments clearly showed that DOM in Sarawak rivers is photolabile, with both DOC mineralisation and substantial changes to the CDOM absorption spectrum occurring within days of sunlight exposure. The linearity of DOC loss with cumulative irradiation in our river samples suggests that our experiments were too short for all photolabile DOC to be lost; our results are therefore an underestimate of the total proportion of tDOC in Sarawak rivers that can potentially be photomineralised (of course, it must be noted that the rate of tDOC photo-oxidation in our incubations was likely much higher than the true in situ rate of photo-oxidation, at least in the highly light absorbent rivers). Only the marine sample did not lose DOC upon exposure to sunlight, although this sample did show a significant increase in $S_{275-295}$ to higher values than found at any of our stations. This increase in spectral slope for marine CDOM further suggests that there was a terrigenous fraction of DOM even at those stations farthest offshore.
High photolability of tDOM has been shown in many cases, with freshwater samples from North America (Gao and Zepp, 1998; Helms et al., 2008, 2014; Miller and Zepp, 1995; White et al., 2010), Africa (Spencer et al., 2009), and the Arctic (Stubbins et al., 2017) showing loss of DOC and changes in absorption spectra upon solar irradiation. In some cases, however, riverine tDOC was found to be resistant to photodegradation, possibly because the photolabile fraction had already degraded upstream of the sampling site (Chupakova et al., 2018). Phytoplankton-produced DOC and marine surface-water DOC are typically not photomineralised (Obernosterer and Benner, 2004; Ziegler and Benner, 2000), although DOC from aphotic deep-sea samples has been shown to be photolabile (Helms et al., 2013). The changes that we observed in all our samples in $S_{275-295}$ (pronounced increase) and in $S_{350-400}$ (decrease or no change relative to dark bottles) upon sunlight exposure, and the resulting increases in $S_{R}$, are also consistent with photodegradation studies of tDOM in other regions (Helms et al., 2013; Spencer et al., 2009). Our data thus validate these optical measures as indicators of photodegradation also in SouthEast Asia. Interestingly, the Samunsam blackwater sample did not show a change in $\mathrm{SUVA}_{254}$ upon solar irradiation. Given the very high $\mathrm{SUVA}_{254}$ of this sample, it is possible that the contribution of aromatic molecules to the total DOC was so high that the degradation of aromatic moieties was proportional to the overall loss of DOC during photoexposure.

Our experimental results thus indicate that $\mathrm{tDOM}$ in rivers in Sarawak contains a significant photolabile fraction that is partly photomodified and partly photomineralised. Because South-East Asian peatlands are predominantly found in coastal lowlands (Dommain et al., 2014), peatland-derived DOM probably has too short a residence time in rivers for significant photodegradation to occur in the rivers before it reaches the sea, unlike in some Arctic rivers (Chupakova et al., 2018). We therefore suggest that most photochemical transformations of tDOC in Sarawak likely take place after tDOC reaches the sea rather than inside the rivers and estuaries.

\subsection{Mixing of riverine DOM with marine water}

\subsubsection{Conservative mixing}

In the Maludam, Samunsam, and Sematan estuaries, DOC and most CDOM parameters showed conservative mixing between river water and seawater. Conservative behaviour of tDOM is often reported from estuaries elsewhere (Chen et al., 2015; Kowalczuk et al., 2003; Rochelle-Newall and Fisher, 2002; Yamashita et al., 2011), including the few South-East Asian rivers that have been studied to date (Alkhatib et al., 2007; Baum et al., 2007; Rixen et al., 2008). Even though tDOM is now recognised as being less refractory than previously assumed (Bauer et al., 2013; Bianchi, 2011; Cai, 
2011), as also shown by our photodegradation experiments, the removal timescales of tDOM by photochemical, biological, and other processes are clearly longer than the transit times through these river systems.

The marine waters in the western region showed a clear seasonal difference in CDOM spectral characteristics and salinity. The only significant rivers in this region are the Samunsam, Sematan, and Lundu. In spite of their small size, these rivers clearly deliver enough tDOM to measurably impact the optical characteristics of the DOM pool in coastal waters $10-20 \mathrm{~km}$ beyond the river mouths, including on the coral reefs surrounding the Talang Islands. Even our highest values of $S_{275-295}$ are actually on the low end of values reported from marine samples (usually $0.020-0.050$, Stedmon and Nelson, 2015), suggesting that tDOM contributes significantly to the total DOM pool in coastal waters in Sarawak. Beyond the immediate river plumes, these coastal waters have low concentrations of suspended sediments and of chlorophyll, which means that tDOM delivery might act as an important control over the underwater light availability in this region and thus over coastal productivity (Cherukuru et al., 2014; Durako et al., 2010; Lawrenz et al., 2010).

\subsubsection{Possible non-conservative mixing in the Rajang}

In the Rajang Delta, we found evidence of non-conservative mixing, with most of the brackish waters having higher DOC concentrations than expected. We attribute this to continued input of tDOC from the extensive peatlands surrounding all of the distributaries (Gastaldo, 2010; Staub et al., 2000), since we observed increasing DOC concentration with distance downstream in each distributary. Moreover, several of the eastern region marine samples, with salinities $>30$, had higher DOC concentrations than predicted by the mixing models, possibly indicating that DOC-rich run-off from peatlands also flows directly into the coastal sea (e.g. from peatlands on Pulau Bruit, Staub et al., 2000). Higher DOC concentrations than predicted by conservative mixing have sometimes been noted, for example in the Chesapeake Bay, and attributed to in situ production of DOC by phytoplankton (Rochelle-Newall and Fisher, 2002). However, chlorophyll$a$ concentrations in our study region very rarely exceeded $2.5 \mu \mathrm{g} \mathrm{L}^{-1}$ and were always below $1 \mu \mathrm{g} \mathrm{L}^{-1}$ in the Rajang River, which rules out phytoplankton production as a major source of riverine DOC.

Given this large input of likely peat-derived DOC into the Rajang Delta, one would also expect non-conservative behaviour from CDOM. Surprisingly, however, the majority of brackish samples actually had higher $S_{275-295}$ values than predicted, contrary to what one would expect from the addition of peatland-derived DOM (indeed, all other rivers had lower $S_{275-295}$ than our Rajang samples). These results suggest that there is selective removal of a high-molecular weight CDOM fraction within the Rajang Delta, despite the continued input of tDOM in the distributaries. Our data from the Sematan River in March actually hint at a similar increase in $S_{275-295}$ than expected from conservative mixing, although our data set from this river is too limited to conclude this with confidence.

Non-conservative removal of tDOM in estuaries can occur due to photodegradation and microbial degradation, flocculation due to rising salinity, or adsorption to sediments. We hypothesise that adsorption of tDOM to suspended inorganic sediments is the most likely explanation for the nonconservative increase in $S_{275-295}$. We measured extremely high suspended inorganic sediment in all of the Rajang distributaries on all expeditions $\left(100-360 \mathrm{mg} \mathrm{L}^{-1}\right)$, which is consistent with previous data (Staub et al., 2000). Such concentrations of sediments have been shown to lower CDOM absorption coefficients and to increase the CDOM spectral slope of estuarine tDOM samples in laboratory incubations (Shank et al., 2005; Uher et al., 2001). While flocculation of tDOM due to rising salinity can occur (Sholkovitz et al., 1978; Uher et al., 2001), we would also expect this process to affect all of the other less sediment-rich rivers similarly, but this was not the case (except possibly in the Sematan estuary). Photodegradation is unlikely to account for CDOM removal in the Rajang Delta because the high sediment loads attenuate light very strongly; Secchi depths, measured on two of our expeditions in the Rajang, were typically in the range of $10-30 \mathrm{~cm}$. Although bacterial degradation of tDOM almost certainly does take place in the Rajang, the transit time of river water through the distributaries is probably too short for biological degradation to account for the observed changes: the total distance through the distributaries to the coast is around $80-120 \mathrm{~km}$, and current speeds of the order of about 1-2 knots were typical, implying a total transit time to sea of just a few days. Sediment adsorption, however, has been shown to alter CDOM spectra within hours to days (Shank et al., 2005; Uher et al., 2001). Müller-Dum et al. (2018) reported relatively low concentrations of $\mathrm{CO}_{2}$ in the Rajang River and along the distributaries, with ${ }^{13} \mathrm{C}$ content of dissolved inorganic carbon indicating little contribution of peatland DOC to the dissolved $\mathrm{CO}_{2}$ pool, which supports our interpretation of the DOC and CDOM data in this river.

\subsection{Biogeochemical processing of tDOM}

Both photodegradation and microbial degradation typically cause increases in $S_{275-295}$ (Helms et al., 2014; Lu et al., 2016; Spencer et al., 2009). However, photodegradation concomitantly reduces $S_{350-400}$, and thus increases $S_{\mathrm{R}}$ (Helms et al., 2013, 2014; Spencer et al., 2009), as seen in all of our photodegradation experiments. In contrast, incubation experiments suggest that bacterial processing of tDOM either has limited impact on or actually increases $S_{350-400}$ (Hansen et al., 2016; Lu et al., 2016). Similarly, Moran et al. (2000) found that CDOM spectral slopes over a larger wavelength range are increased by photodegradation but reduced by mi- 
crobial degradation. The fact that $S_{\mathrm{R}}$ showed a very clear increase with salinity in all rivers, with marine samples mostly showing values $>1.0$, suggests that photodegradation plays an important role in processing $\mathrm{tDOM}$ in this region. However, the erratic variation seen in $S_{350-400}$, with marine samples having either higher or lower values than river water, may be indicative of a role for microbial tDOM degradation as well. Typically, photodegradation makes tDOM more labile to microbial remineralisation (Kieber et al., 1989; Miller and Moran, 1997; Obernosterer and Benner, 2004), which makes it hard to disentangle the importance of the two processes based only on CDOM measurements. While our CDOM data are consistent with an important role for photodegradation, estimating the amount of tDOC that is actually photo-oxidised to inorganic carbon would require estimates of the water residence time, solar irradiation, and light attenuation coefficients, which are not available for Sarawak at the present time. Based on this calculation, Fichot and Benner (2014) estimated that the majority of tDOC delivered by the Mississippi River to the Gulf of Mexico is actually remineralised by bacteria, even though the tDOC in their study region was found to be photolabile in irradiation experiments.

Importantly, our data suggest that most of the tDOM that is lost from South-East Asia's coastal peatlands is transferred to the seas on the Sunda Shelf, where it becomes part of the global ocean circulation via the different branches of the Indonesian Throughflow. However, owing to the large geographical extent of the Sunda Shelf, the residence time of peatland tDOM on the shelf is likely to be at least several months to a year. During this time, the tDOM always experiences temperatures of $25-30^{\circ} \mathrm{C}$ (promoting rapid microbial metabolism) and is also likely exposed to relatively high doses of solar irradiation, because these oligotrophic, tropical waters are relatively clear and shallow (mostly $<100 \mathrm{~m}$ deep). The geographical extent and oceanography of the Sunda Shelf seas are therefore likely to strongly promote the remineralisation of tDOM before this material enters the open ocean. Remineralisation of tDOC would explain the high $p \mathrm{CO}_{2}$ oversaturation reported by Kartadikaria et al. (2015) across the Java Sea, which is thus consistent with our results.

\section{Conclusions}

We have undertaken the first seasonally resolved study of DOC and CDOM for South-East Asia that includes peatlanddraining rivers, estuaries, and coastal waters. Most of the rivers we sampled carried very high concentrations of tDOC and CDOM that showed conservative mixing with seawater in the estuaries. Non-conservative mixing was only found in the Rajang River delta, where our data point towards increasing inputs of tDOM from peatlands along the delta but also to the removal of a high-molecular weight fraction, prob- ably due to adsorption to sediments. Seasonality in tDOM concentrations differed between rivers, but our CDOM data showed that tDOM concentrations were higher at all marine stations in the western part of our study region during the north-east monsoon. Overall, our CDOM spectral slope coefficients are consistent with a significant contribution by tDOM to the total DOM pool even at our marine endmember stations but also suggest that photodegradation plays an important role in the biogeochemical processing of tDOM in Sarawak's coastal waters. This is also supported by our direct experimental evidence showing that tDOM from rivers in Sarawak is both remineralised and altered upon solar irradiation. Our results therefore suggest that much of the biogeochemical processing of peatland-derived tDOM in SouthEast Asia may take place in shelf seas rather than rivers.

Data availability. The full processed data set for all parameters is available as Table $\mathrm{S} 1$. All raw data files are available through the NTU data repository, DR-NTU, at https://doi.org/10.21979/N9/0RLSDU (Martin, 2018).

Supplement. The supplement related to this article is available online at: https://doi.org/10.5194/bg-15-6847-2018-supplement.

Author contributions. PM, MM, NC, NS, and AM conceptualised the research project and planned the field expeditions. PM, MM, $\mathrm{AM}$, and NC obtained research funding. PM, MM, NC, ASYT, and AM collected and analysed the field samples. PM, ASYT, and NS processed and analysed the data. All authors contributed to data interpretation and to the writing of the manuscript.

Competing interests. The authors declare that they have no conflict of interest.

Special issue statement. This article is part of the special issue "Biogeochemical processes in highly dynamic peat-draining rivers and estuaries in Borneo". It is not associated with a conference.

Acknowledgements. We would like to thank the Sarawak Forestry Department and Sarawak Biodiversity Centre for permission to conduct collaborative research in Sarawak waters under permit numbers NPW.907.4.4(Jld.14)-161, Park Permit no. WL83/2017, and SBC-RA-0097-MM. We are very grateful to the boatmen who helped us to collect samples, in particular Lukas Chin, Captain Juble, and their crew during the Rajang River and eastern region cruises, and Minhad and Pak Mat while sampling the western region. We are grateful to Claire Evans and Joost Brandsma for their participation in planning the overall research project and helping to lead expeditions to the Maludam, Sebuyau, and Simunjan rivers. Faddrine Jang, Edwin Sia, Gonzalo Carrasco, Jack Sim, Akhmetzada Kargazhanov, Florina Richard, Faith 
Chaya, Noor Iskandar Noor Azhar, and Fakharuddin Muhamad assisted greatly during fieldwork and with logistics. The Sarawak Department of Irrigation and Drainage provided precipitation data. Patrick Martin acknowledges funding through a Nanyang Technological University Start-Up Grant, and a Tier 1 grant from the Singapore Ministry of Education's Academic Research Fund (RG 175/16). Mortiz Müller and Aazani Mujahid were funded by MOHE FRGS 15 Grant (FRGS/1/2015/WAB08/SWIN/02/1), SKLEC Open Research Fund (SKLEC-KF201610), and by the Newton-Ungku Omar Fund (GL/F07/NUOF/01/2017). Nagur Cherukuru acknowledges the CSIRO Coasts programme funding contribution for this research. A CSIRO internal review helped to improve the manuscript. We thank two anonymous reviewers for constructive criticism that improved the manuscript.

Edited by: Palanisamy Shanmugam

Reviewed by: two anonymous referees

\section{References}

Alkhatib, M., Jennerjahn, T. C., and Samiaji, J.: Biogeochemistry of the Dumai River estuary, Sumatra, Indonesia, a tropical black-water river, Limnol. Oceanogr., 52, 2410-2417, https://doi.org/10.4319/1o.2007.52.6.2410, 2007.

Bauer, J. E., Cai, W.-J., Raymond, P. A., Bianchi, T. S., Hopkinson, C. S., and Regnier, P. A. G.: The changing carbon cycle of the coastal ocean, Nature, 504, 61-70, https://doi.org/10.1038/nature12857, 2013.

Baum, A., Rixen, T., and Samiaji, J.: Relevance of peat draining rivers in central Sumatra for the riverine input of dissolved organic carbon into the ocean, Estuar. Coast. Shelf S., 73, 563-570, https://doi.org/10.1016/j.ecss.2007.02.012, 2007.

Beleites, C. and Sergo, V.: hyperSpec: a package to handle hyperspectral data sets in R, available at: http://hyperspec.r-forge. r-project.org, last access: 14 November 2018.

Benner, R., Louchouarn, P., and Amon, R. M. W.: Terrigenous dissolved organic matter in the Arctic Ocean and its transport to surface and deep waters of the North Atlantic, Global Biogeochem. Cy., 19, GB2025, https://doi.org/10.1029/2004GB002398, 2005.

Bianchi, T. S.: The role of terrestrially derived organic carbon in the coastal ocean: A changing paradigm and the priming effect, $P$. Natl. Acad. Sci. USA, 108, 19473-19481, 2011.

Cai, W.-J.: Estuarine and coastal ocean carbon paradox: $\mathrm{CO}_{2}$ sinks or sites of terrestrial carbon incineration?, Annu. Rev. Mar. Sci., 3, 123-145, https://doi.org/10.1146/annurev-marine120709-142723, 2011.

Chen, Z., Doering, P. H., Ashton, M., and Orlando, B. A.: Mixing Behavior of Colored Dissolved Organic Matter and Its Potential Ecological Implication in the Caloosahatchee River Estuary, Florida, Estuaries Coasts, 38, 1706-1718, https://doi.org/10.1007/s12237-014-9916-0, 2015.

Cherukuru, N., Brando, V. E., Schroeder, T., Clementson, L. A., and Dekker, A. G.: Influence of river discharge and ocean currents on coastal optical properties, Cont. Shelf Res., 84, 188-203, https://doi.org/10.1016/j.csr.2014.04.022, 2014.

Chupakova, A. A., Chupakov, A. V., Neverova, N. V., Shirokova, L. S., and Pokrovsky, O. S.: Photodegradation of river dissolved organic matter and trace metals in the largest Euro- pean Arctic estuary, Sci. Total Environ., 622-623, 1343-1352, https://doi.org/10.1016/j.scitotenv.2017.12.030, 2018.

Clark, J. M., Lane, S. N., Chapman, P. J., and Adamson, J. K.: Export of dissolved organic carbon from an upland peatland during storm events: Implications for flux estimates, J. Hydrol., 347, 438-447, https://doi.org/10.1016/j.jhydrol.2007.09.030, 2007.

Cobb, A. R., Hoyt, A. M., Gandois, L., Eri, J., Dommain, R., Abu Salim, K., Kai, F. M., Haji Su'ut, N. S., and Harvey, C. F.: How temporal patterns in rainfall determine the geomorphology and carbon fluxes of tropical peatlands, P. Natl. Acad. Sci. USA, 114, E5187-E5196, https://doi.org/10.1073/pnas.1701090114, 2017.

Cook, S., Peacock, M., Evans, C. D., Page, S. E., Whelan, M. J., Gauci, V., and Kho, L. K.: Quantifying tropical peatland dissolved organic carbon (DOC) using UV-visible spectroscopy, Water Res., 115, 229-235, https://doi.org/10.1016/j.watres.2017.02.059, 2017.

Cook, S., Whelan, M. J., Evans, C. D., Gauci, V., Peacock, M., Garnett, M. H., Kho, L. K., Teh, Y. A., and Page, S. E.: Fluvial organic carbon fluxes from oil palm plantations on tropical peatland, Biogeosciences Discuss., https://doi.org/10.5194/bg-2018417, in review, 2018.

Dai, M., Yin, Z., Meng, F., Liu, Q., and Cai, W.-J.: Spatial distribution of riverine DOC inputs to the ocean: an updated global synthesis, Curr. Opin. Environ. Sust., 4, 170-178, https://doi.org/10.1016/j.cosust.2012.03.003, 2012.

Dittmar, T.: Evidence for terrigenous dissolved organic nitrogen in the Arctic deep sea, Limnol. Oceanogr., 49, 148-156, https://doi.org/10.4319/lo.2004.49.1.0148, 2004.

Dommain, R., Couwenberg, J., Glaser, P. H., Joosten, H., and Suryadiputra, I. N. N.: Carbon storage and release in Indonesian peatlands since the last deglaciation, Quaternary Sci. Rev., 97, 1-32, https://doi.org/10.1016/j.quascirev.2014.05.002, 2014.

Durako, M. J., Kowalczuk, P., Mallin, M. A., Cooper, W. J., Souza, J. J., and Wells, D. H.: Interannual Variation in Photosynthetically Significant Optical Properties and Water Quality in a Coastal Blackwater River Plume, Estuaries Coasts, 33, 14301441, https://doi.org/10.1007/s12237-010-9302-5, 2010.

Fally, S., Vandaele, A. C., Carleer, M., Hermans, C., Jenouvrier, A., Mérienne, M. F., Coquart, B., and Colin, R.: Fourier Transform Spectroscopy of the $\mathrm{O}_{2}$ Herzberg Bands. III. Absorption Cross Sections of the Collision-Induced Bands and of the Herzberg Continuum, J. Mol. Spectrosc., 204, 10-20, https://doi.org/10.1006/jmsp.2000.8204, 2000.

Fasching, C., Behounek, B., Singer, G. A., and Battin, T. J.: Microbial degradation of terrigenous dissolved organic matter and potential consequences for carbon cycling in brown-water streams, Sci. Rep.-UK, 4, 4981, https://doi.org/10.1038/srep04981, 2014.

Fichot, C. G. and Benner, R.: A novel method to estimate DOC concentrations from CDOM absorption coefficients in coastal waters, Geophys. Res. Lett., 38, L03610, https://doi.org/10.1029/2010GL046152, 2011.

Fichot, C. G. and Benner, R.: The spectral slope coefficient of chromophoric dissolved organic matter $\left(S_{275-295}\right)$ as a tracer of terrigenous dissolved organic carbon in riverinfluenced ocean margins, Limnol. Oceanogr., 57, 1453-1466, https://doi.org/10.4319/lo.2012.57.5.1453, 2012.

Fichot, C. G. and Benner, R.: The fate of terrigenous dissolved organic carbon in a river-influenced 
ocean margin, Global Biogeochem. Cy., 28, 300-318, https://doi.org/10.1002/2013GB004670, 2014.

Fichot, C. G., Lohrenz, S. E., and Benner, R.: Pulsed, crossshelf export of terrigenous dissolved organic carbon to the Gulf of Mexico, J. Geophys. Res.-Oceans, 119, 1176-1194, https://doi.org/10.1002/2013JC009424, 2014.

Fichot, C. G., Benner, R., Kaiser, K., Shen, Y., Amon, R. M. W., Ogawa, H., and Lu, C.-J.: Predicting Dissolved Lignin Phenol Concentrations in the Coastal Ocean from Chromophoric Dissolved Organic Matter (CDOM) Absorption Coefficients, Front. Mar. Sci., 3, 7, https://doi.org/10.3389/fmars.2016.00007, 2016.

Gandois, L., Cobb, A. R., Hei, I. C., Lim, L. B. L., Salim, K. A., and Harvey, C. F.: Impact of deforestation on solid and dissolved organic matter characteristics of tropical peat forests: implications for carbon release, Biogeochemistry, 114, 183-199, https://doi.org/10.1007/s10533-012-9799-8, 2013.

Gandois, L., Teisserenc, R., Cobb, A. R., Chieng, H. I., Lim, L. B. L., Kamariah, A. S., Hoyt, A., and Harvey, C. F.: Origin, composition, and transformation of dissolved organic matter in tropical peatlands, Geochim. Cosmochim. Ac., 137, 35-47, https://doi.org/10.1016/j.gca.2014.03.012, 2014.

Gao, H. and Zepp, R. G.: Factors Influencing Photoreactions of Dissolved Organic Matter in a Coastal River of the Southeastern United States, Environ. Sci. Technol., 32, 2940-2946, https://doi.org/10.1021/es9803660, 1998.

Gastaldo, R. A.: Peat or no peat: Why do the Rajang and Mahakam Deltas differ?, Int. J. Coal. Geol., 83, 162-172, https://doi.org/10.1016/j.coal.2010.01.005, 2010.

Green, S. A. and Blough, N. V.: Optical absorption and fluorescence properties of chromophoric dissolved organic matter in natural waters, Limnol. Oceanogr., 39, 1903-1916, 1994.

Guenther, E. A., Johnson, K. S., and Coale, K. H.: Direct ultraviolet spectrophotometric determination of total sulfide and iodide in natural waters, Anal. Chem., 73, 3481-3487, https://doi.org/10.1021/ac0013812, 2001.

Hansen, A. M., Kraus, T. E. C., Pellerin, B. A., Fleck, J. A., Downing, B. D., and Bergamaschi, B. A.: Optical properties of dissolved organic matter (DOM): Effects of biological and photolytic degradation, Limnol. Oceanogr., 61, 1015-1032, https://doi.org/10.1002/lno.10270, 2016.

Harun, S., Baker, A., Bradley, C., and Pinay, G.: Spatial and seasonal variations in the composition of dissolved organic matter in a tropical catchment: the Lower Kinabatangan River, Sabah, Malaysia, Environ. Sci.-Proc. Imp., 18, 137-150, https://doi.org/10.1039/c5em00462d, 2016.

Helms, J. R., Stubbins, A., Ritchie, J. D., Minor, E. C., Kieber, D. J., and Mopper, K.: Absorption spectral slopes and slope ratios as indicators of molecular weight, source, and photobleaching of chromophoric dissolved organic matter, Limnol. Oceanogr., 53, 955-969, https://doi.org/10.4319/lo.2008.53.3.0955, 2008.

Helms, J. R., Stubbins, A., Perdue, E. M., Green, N. W., Chen, H., and Mopper, K.: Photochemical bleaching of oceanic dissolved organic matter and its effect on absorption spectral slope and fluorescence, Mar. Chem., 155, 81-91, https://doi.org/10.1016/j.marchem.2013.05.015, 2013.

Helms, J. R., Mao, J., Stubbins, A., Schmidt-Rohr, K., Spencer, R. G. M., Hernes, P. J., and Mopper, K.: Loss of optical and molecular indicators of terrigenous dissolved organic mat- ter during long-term photobleaching, Aquat. Sci., 76, 353-373, https://doi.org/10.1007/s00027-014-0340-0, 2014.

Huang, T. H., Chen, C. T. A., Tseng, H. C., Lou, J. Y., Wang, S. L., Yang, L., Kandasamy, S., Gao, X., Wang, J. T., Aldrian, E., Jacinto, G. S., Anshari, G. Z., Sompongchaiyakul, P., and Wang, B. J.: Riverine carbon fluxes to the South China Sea, J. Geophys. Res.-Biogeo., 122, 1239-1259, https://doi.org/10.1002/2016JG003701, 2017.

Kaiser, K., Benner, R., and Amon, R. M. W.: The fate of terrigenous dissolved organic carbon on the Eurasian shelves and export to the North Atlantic, J. Geophys. Res.-Oceans, 122, 4-22, https://doi.org/10.1002/2016JC012380, 2017.

Kartadikaria, A. R., Watanabe, A., Nadaoka, K., Adi, N. S., Prayitno, H. B., Soemorumekso, S., Muchtar, M., Triyulianti, I., Setiawan, A., Suratno, S., and Khasanah, E. $\mathrm{N}$.: $\mathrm{CO}_{2}$ sink/source characteristics in the tropical Indonesian seas, J. Geophys. Res.-Oceans, 120, 7842-7856, https://doi.org/10.1002/2015JC010925, 2015.

Kieber, D. J., McDaniel, J., and Mopper, K.: Photochemical source of biological substrates in sea water: implications for carbon cycling, Nature, 341, 637-639, https://doi.org/10.1038/341637a0, 1989.

Kieber, R. J., Whitehead, R. F., and Skrabal, S. A.: Photochemical production of dissolved organic carbon from resuspended sediments, Limnol. Oceanogr., 51, 2187-2195, https://doi.org/10.4319/lo.2006.51.5.2187, 2006.

Kowalczuk, P., Cooper, W. J., Whitehead, R. F., Durako, M. J., and Sheldon, W.: Characterization of CDOM in an organic-rich river and surrounding coastal ocean in the South Atlantic Bight, Aquat. Sci., 65, 384-401, https://doi.org/10.1007/s00027-0030678-1, 2003.

Lawrenz, E., Pinckney, J. L., Ranhofer, M. L., MacIntyre, H. L., and Richardson, T. L.: Spectral Irradiance and Phytoplankton Community Composition in a Blackwater-Dominated Estuary, Winyah Bay, South Carolina, USA, Estuaries Coasts, 33, 11861201, https://doi.org/10.1007/s12237-010-9310-5, 2010.

Leech, D. M., Ensign, S. H., and Piehler, M. F.: Spatiotemporal patterns in the export of dissolved organic carbon and chromophoric dissolved organic matter from a coastal, blackwater river, Aquat Sci., 78, 823-836, https://doi.org/10.1007/s00027-016-0474-3, 2016.

Leff, L. G. and Meyer, J. L.: Biological availability of dissolved organic carbon along the Ogeechee River, Limnol. Oceanogr., 36, 315-323, 1991.

Lu, C.-J., Benner, R., Fichot, C. G., Fukuda, H., Yamashita, Y., and Ogawa, H.: Sources and Transformations of Dissolved Lignin Phenols and Chromophoric Dissolved Organic Matter in Otsuchi Bay, Japan, Front. Mar. Sci., 3, 85, https://doi.org/10.3389/fmars.2016.00085, 2016.

Martin, P.: Replication Data for: Distribution and cycling of terrigenous dissolved organic carbon in peatlanddraining rivers and coastal waters of Sarawak, Borneo, https://doi.org/10.21979/N9/0RLSDU, DR-NTU (Data), V2, 2018.

Massicotte, P., Asmala, E., Stedmon, C., and Markager, S.: Global distribution of dissolved organic matter along the aquatic continuum: Across rivers, lakes and oceans, Sci. Total Environ., 609, 180-191, https://doi.org/10.1016/j.scitotenv.2017.07.076, 2017. 
Materić, D., Peacock, M., Kent, M., Cook, S., Gauci, V., Röckmann, T., and Holzinger, R.: Characterisation of the semi-volatile component of Dissolved Organic Matter by Thermal Desorption Proton Transfer Reaction - Mass Spectrometry, Sci. Rep.-UK, 7, 15936, https://doi.org/10.1038/s41598-017-16256-x, 2017.

Mayer, L. M., Schick, L. L., Skorko, K., and Boss, E.: Photodissolution of particulate organic matter from sediments, Limnol. Oceanogr., 51, 1064-1071, https://doi.org/10.4319/lo.2006.51.2.1064, 2006.

Medeiros, P. M., Seidel, M., Niggemann, J., Spencer, R. G. M., Hernes, P. J., Yager, P. L., Miller, W. L., Dittmar, T., and Hansell, D. A.: A novel molecular approach for tracing terrigenous dissolved organic matter into the deep ocean, Global Biogeochem. Cy., 30, 689-699, https://doi.org/10.1002/2015GB005320, 2016.

Medeiros, P. M., Babcock-Adams, L., Seidel, M., Castelao, R. M., Di Iorio, D., Hollibaugh, J. T., and Dittmar, T.: Export of terrigenous dissolved organic matter in a broad continental shelf, Limnol. Oceanogr., 62, 1718-1731, https://doi.org/10.1002/lno.10528, 2017.

Miettinen, J., Shi, C., and Liew, S. C.: Land cover distribution in the peatlands of Peninsular Malaysia, Sumatra and Borneo in 2015 with changes since 1990, Glob. Ecol. Conserv., 6, 67-78, https://doi.org/10.1016/j.gecco.2016.02.004, 2016.

Miller, W. L. and Moran, M. A.: Interaction of photochemical and microbial processes in the degradation of refractory dissolved organic matter from a coastal marine environment, Limnol. Oceanogr., 42, 1317-1324, https://doi.org/10.4319/1o.1997.42.6.1317, 1997.

Miller, W. L. and Zepp, R. G.: Photochemical production of dissolved inorganic carbon from terrestrial organic matter: Significance to the oceanic organic carbon cycle, Geophys. Res. Lett., 22, 417-420, https://doi.org/10.1029/94GL03344, 1995.

Mitchell, G., Bricaud, A., Carder, K., Cleveland, J., Ferrari, G., Gould, R., Kahru, M., Kishino, M., Maske, H., Moisan, T., Moore, L., Nelson, N., Phinney, D., Reynolds, R., Sosik, H., Stramski, D., Tassan, S., Trees, C. C., Weidemann, A., Wieland, J., and Vodacek, A.: Determination of spectral absorption coefficients of particles, dissolved material and phytoplankton for discrete water samples, in: Ocean Optics Protocols for Satellite Ocean Color Sensor Validation, Revision 2, edited by: Fargion, G. S. and Mueller, J. L., National Aeronautical and Space Administration, Greenbelt, Maryland, 125-153, 2000.

Moore, S., Gauci, V., Evans, C. D., and Page, S. E.: Fluvial organic carbon losses from a Bornean blackwater river, Biogeosciences, 8, 901-909, https://doi.org/10.5194/bg-8-901-2011, 2011.

Moore, S., Evans, C. D., Page, S. E., Garnett, M. H., Jones, T. G., Freeman, C., Hooijer, A., Wiltshire, A. J., Limin, S. H., and Gauci, V.: Deep instability of deforested tropical peatlands revealed by fluvial organic carbon fluxes, Nature, 493, 660-663, https://doi.org/10.1038/nature11818, 2013.

Moran, M. A. and Hodson, R. E.: Bacterial production on humic and nonhumic components of dissolved organic carbon, Limnol. Oceanogr., 35, 1744-1756, https://doi.org/10.4319/lo.1990.35.8.1744, 1990.

Moran, M. A., Sheldon, W. M., and Zepp, R. G.: Carbon loss and optical property changes during long-term photochemical and biological degradation of estuarine dissolved organic matter, Limnol. Oceanogr., 45, 1254-1264, https://doi.org/10.4319/1o.2000.45.6.1254, 2000.
Müller, D., Warneke, T., Rixen, T., Müller, M., Jamahari, S., Denis, N., Mujahid, A., and Notholt, J.: Lateral carbon fluxes and $\mathrm{CO}_{2}$ outgassing from a tropical peat-draining river, Biogeosciences, 12, 5967-5979, https://doi.org/10.5194/bg-12-5967-2015, 2015.

Müller, D., Warneke, T., Rixen, T., Müller, M., Mujahid, A., Bange, H. W., and Notholt, J.: Fate of terrestrial organic carbon and associated $\mathrm{CO}_{2}$ and $\mathrm{CO}$ emissions from two Southeast Asian estuaries, Biogeosciences, 13, 691-705, https://doi.org/10.5194/bg13-691-2016, 2016.

Müller-Dum, D., Warneke, T., Rixen, T., Müller, M., Baum, A., Christodoulou, A., Oakes, J., Eyre, B. D., and Notholt, J.: Impact of peatlands on carbon dioxide $\left(\mathrm{CO}_{2}\right)$ emissions from the Rajang River and Estuary, Malaysia, Biogeosciences Discuss., https://doi.org/10.5194/bg-2018-391, in review, 2018.

Obernosterer, I. and Benner, R.: Competition between biological and photochemical processes in the mineralization of dissolved organic carbon, Limnol. Oceanogr., 49, 117-124, https://doi.org/10.4319/lo.2004.49.1.0117, 2004.

Osburn, C. L., Boyd, T. J., Montgomery, M. T., Bianchi, T. S., Coffin, R. B., and Paerl, H. W.: Optical Proxies for Terrestrial Dissolved Organic Matter in Estuaries and Coastal Waters, Front. Mar. Sci., 2, 127, https://doi.org/10.3389/fmars.2015.00127, 2016.

Page, S. E., Rieley, J. O., and Banks, C. J.: Global and regional importance of the tropical peatland carbon pool, Glob. Change Biol., 17, 798-818, https://doi.org/10.1111/j.13652486.2010.02279.x, 2011.

Painter, S. C., Lapworth, D. J., Woodward, E. M. S., Kroeger, S., Evans, C. D., Mayor, D. J., and Sanders, R. J.: Terrestrial dissolved organic matter distribution in the North Sea, Sci. Total Environ., 630, 630-647, https://doi.org/10.1016/j.scitotenv.2018.02.237, 2018.

Rathgeb, A., Causon, T., Krachler, R., and Hann, S.: From the peat bog to the estuarine mixing zone: Common features and variances in riverine dissolved organic matter determined by non-targeted analysis, Mar. Chem., 194, 158-167, https://doi.org/10.1016/j.marchem.2017.06.012, 2017.

Riggsbee, J. A., Orr, C. H., Leech, D. M., Doyle, M. W., and Wetzel, R. G.: Suspended sediments in river ecosystems: Photochemical sources of dissolved organic carbon, dissolved organic nitrogen, and adsorptive removal of dissolved iron, J. Geophys. Res.Biogeo., 113, G03019, https://doi.org/10.1029/2007JG000654, 2008.

Rixen, T., Baum, A., Pohlmann, T., Balzer, W., Samiaji, J., and Jose, C.: The Siak, a tropical black water river in central Sumatra on the verge of anoxia, Biogeochemistry, 90, 129-140, https://doi.org/10.1007/s10533-008-9239-y, 2008.

Rochelle-Newall, E. J. and Fisher, T. R.: Chromophoric dissolved organic matter and dissolved organic carbon in Chesapeake Bay, Mar. Chem., 77, 23-41, https://doi.org/10.1016/S03044203(01)00073-1, 2002.

Sa'adi, Z., Shahid, S., Ismail, T., Chung, E.-S., and Wang, X.-J.: Distributional changes in rainfall and river flow in Sarawak, Malaysia, Asia Pac. J. Atmos. Sci., 53, 489-500, https://doi.org/10.1007/s13143-017-0051-2, 2017.

Semiletov, I., Pipko, I., Gustafsson, O., Anderson, L. G., Sergienko, V., Pugach, S., Dudarev, O., Charkin, A., Gukov, A., Broder, L., Andersson, A., Spivak, E., and Shakhova, N.: Acidification of East Siberian Arctic Shelf waters through addition of 
freshwater and terrestrial carbon, Nat. Geosci., 9, 361-365, https://doi.org/10.1038/ngeo2695, 2016.

Shank, G. C., Zepp, R. G., Whitehead, R. F., and Moran, M. A.: Variations in the spectral properties of freshwater and estuarine CDOM caused by partitioning onto river and estuarine sediments, Estuar. Coast. Shelf S., 65, 289-301, https://doi.org/10.1016/j.ecss.2005.06.009, 2005.

Sholkovitz, E. R., Boyle, E. A., and Price, N. B.: The removal of dissolved humic acids and iron during estuarine mixing, Earth. Planet. Sc. Lett., 40, 130-136, https://doi.org/10.1016/0012821X(78)90082-1, 1978.

Spencer, R. G. M., Stubbins, A., Hernes, P. J., Baker, A., Mopper, K., Aufdenkampe, A. K., Dyda, R. Y., Mwamba, V. L., Mangangu, A. M., Wabakanghanzi, J. N., and Six, J.: Photochemical degradation of dissolved organic matter and dissolved lignin phenols from the Congo River, J. Geophys. Res.-Biogeo., 114, G03010, https://doi.org/10.1029/2009JG000968, 2009.

Staub, J. R., Among, H. L., and Gastaldo, R. A.: Seasonal sediment transport and deposition in the Rajang River delta, Sarawak, East Malaysia, Sediment. Geol., 133, 249-264, https://doi.org/10.1016/S0037-0738(00)00042-7, 2000.

Stedmon, C. A., Markager, S., and Kaas, H.: Optical Properties and Signatures of Chromophoric Dissolved Organic Matter (CDOM) in Danish Coastal Waters, Estuar. Coast. Shelf S., 51, 267-278, https://doi.org/10.1006/ecss.2000.0645, 2000.

Stedmon, C. A. and Markager, S.: Behaviour of the optical properties of coloured dissolved organic matter under conservative mixing, Estuar. Coast. Shelf S., 57, 973-979, https://doi.org/10.1016/S0272-7714(03)00003-9, 2003.

Stedmon, C. A. and Nelson, N. B.: The Optical Properties of DOM in the Ocean, in: Biogeochemistry of Marine Dissolved Organic Matter (Second Edition), edited by: Carlson, C. A., Academic Press, Boston, 481-508, 2015.

Stubbins, A., Mann, P. J., Powers, L., Bittar, T. B., Dittmar, T., McIntyre, C. P., Eglinton, T. I., Zimov, N., and Spencer, R. G. M.: Low photolability of yedoma permafrost dissolved organic carbon, J. Geophys. Res.-Biogeo., 122, 200-211, https://doi.org/10.1002/2016JG003688, 2017.

Stutter, M. I. and Cains, J.: The mineralisation of dissolved organic matter recovered from temperate waterbodies during summer, Aquat. Sci., 78, 447-462, https://doi.org/10.1007/s00027015-0446-z, 2016.

Tilstone, G. H., Moore, G. F., Sørensen, K., Doerffer, R., Røttgers, R., Ruddick, K. G., Pasterkamp, R., and Jørgensen, P. V.: REVAMP: Regional Validation of MERIS Chlorophyll Products in North Sea Coastal Waters, Proceedings of the Working Meeting on MERIS and AATSR Calibration and Geophysical Validation (ENVISAT MAVT-2003), ESA Special Publication WPP-233, 2002.
Traina, S. J., Novak, J., and Smeck, N. E.: An ultraviolet absorbance method of estimating the percent aromatic carbon content of humic acids, J. Environ. Qual., 19, 151-153, 1990.

Uher, G., Hughes, C., Henry, G., and Upstill-Goddard, R. C.: Nonconservative mixing behavior of colored dissolved organic matter in a humic-rich, turbid estuary, Geophys. Res. Lett., 28, 33093312, https://doi.org/10.1029/2000GL012509, 2001.

Ward, N. D., Keil, R. G., Medeiros, P. M., Brito, D. C., Cunha, A. C., Dittmar, T., Yager, P. L., Krusche, A. V., and Richey, J. E.: Degradation of terrestrially derived macromolecules in the Amazon River, Nat. Geosci., 6, 530-533, https://doi.org/10.1038/ngeo1817, 2013.

Weishaar, J. L., Aiken, G. R., Bergamaschi, B. A., Fram, M. S., Fujii, R., and Mopper, K.: Evaluation of Specific Ultraviolet Absorbance as an Indicator of the Chemical Composition and Reactivity of Dissolved Organic Carbon, Environ. Sci. Technol., 37, 4702-4708, https://doi.org/10.1021/es030360x, 2003.

Welschmeyer, N. A.: Fluorometric analysis of chlorophyll $a$ in the presence of chlorophyll $b$ and pheopigments, Limnol. Oceanogr., 39, 1985-1992, 1994.

White, E. M., Kieber, D. J., Sherrard, J., Miller, W. L., and Mopper, K.: Carbon dioxide and carbon monoxide photoproduction quantum yields in the Delaware Estuary, Mar. Chem., 118, 1121, https://doi.org/10.1016/j.marchem.2009.10.001, 2010.

Wit, F., Müller, D., Baum, A., Warneke, T., Pranowo, W. S., Müller, M., and Rixen, T.: The impact of disturbed peatlands on river outgassing in Southeast Asia, Nat. Commun., 6, 10155, https://doi.org/10.1038/ncomms10155, 2015.

Yamashita, Y., Panton, A., Mahaffey, C., and Jaffé, R.: Assessing the spatial and temporal variability of dissolved organic matter in Liverpool Bay using excitation-emission matrix fluorescence and parallel factor analysis, Ocean Dynam., 61, 569-579, https://doi.org/10.1007/s10236-010-0365-4, 2011.

Ziegler, S. and Benner, R.: Effects of solar radiation on dissolved organic matter cycling in a subtropical seagrass meadow, Limnol. Oceanogr., 45, 257-266, https://doi.org/10.4319/lo.2000.45.2.0257, 2000.

Zigah, P. K., McNichol, A. P., Xu, L., Johnson, C., Santinelli, C., Karl, D. M., and Repeta, D. J.: Allochthonous sources and dynamic cycling of ocean dissolved organic carbon revealed by carbon isotopes, Geophys. Res. Lett., 44, 2407-2415, https://doi.org/10.1002/2016GL071348, 2017. 